\title{
Synthesis, Carbonic Anhydrase II/IX/XII Inhibition, DFT, and Molecular Docking Studies of Hydrazide-Sulfonamide Hybrids of 4-Methylsalicyl- and Acyl-Substituted Hydrazide
}

\author{
Adil Khushal, ${ }^{1}$ Amara Mumtaz ${ }^{\mathbb{D}},{ }^{1}$ Wamda Ahmed Shadoul, ${ }^{2}$ Syeda Huda Mehdi Zaidi, ${ }^{3}$ \\ Hummera Rafique, ${ }^{4}$ Abida Munir, ${ }^{1}$ Aneela Maalik, ${ }^{5}$ Syed Jawad Ali Shah, ${ }^{2}$ Ayesha Baig, \\ Wajiha Khawaja, ${ }^{1}$ Mariya al-Rashida, ${ }^{7}$ Muhammad Ali Hashmi $\mathbb{D},{ }^{3}$ and Jamshed Iqbal $\mathbb{D}^{2}$ \\ ${ }^{1}$ Department of Chemistry, COMSATS University Islamabad, Abbottabad Campus, Pakistan \\ ${ }^{2}$ Center for Advance Drug Research, COMSATS University Islamabad, Abbottabad Campus, Pakistan \\ ${ }^{3}$ Department of Chemistry, University of Education, Attock Campus Attock 43600, Pakistan \\ ${ }^{4}$ Department of Chemistry, University of Gujrat, Gujrat, Pakistan \\ ${ }^{5}$ Department of Chemistry, COMSATS University Islamabad, Islamabad Campus, Pakistan \\ ${ }^{6}$ Department of Biotechnology, COMSATS University Islamabad, Abbottabad Campus, Pakistan \\ ${ }^{7}$ Department of Chemistry, Forman Christian College, Lahore, Pakistan
}

Correspondence should be addressed to Amara Mumtaz; amaramumtaz@cuiatd.edu.pk and Jamshed Iqbal; jamshediqb@googlemail.com

Received 1 September 2021; Revised 30 December 2021; Accepted 4 January 2022; Published 24 February 2022

Academic Editor: Nahide Gulsah Deniz

Copyright (C) 2022 Adil Khushal et al. This is an open access article distributed under the Creative Commons Attribution License, which permits unrestricted use, distribution, and reproduction in any medium, provided the original work is properly cited.

\begin{abstract}
Carbonic anhydrases (CAs and EC 4.2.1.1) are the $\mathrm{Zn}^{2+}$ containing enzymes which catalyze the reversible hydration of $\mathrm{CO}_{2}$ to carbonate and proton. If they are not functioning properly, it would lead towards many diseases including tumor. Synthesis of hydrazide-sulfonamide hybrids (19-36) was carried out by the reaction of aryl (10-11) and acyl (12-13) hydrazides with substituted sulfonyl chloride (14-18). Final product formation was confirmed by FT-IR, NMR, and EI-MS. Density functional theory (DFT) calculations were performed on all the synthesized compounds to get the ground-state geometries and compute NMR properties. NMR computations were in excellent agreement with the experimental NMR data. All the synthesized hydrazide-sulfonamide hybrids were in vitro evaluated against CA II, CA IX, and CA XII isozymes for their carbonic anhydrase inhibition activities. Among the entire series, only compounds 22, 32, and 36 were highly selective inhibitors of $h \mathrm{CA}$ IX and did not inhibit $h \mathrm{CA}$ XII. To investigate the binding affinity of these compounds, molecular docking studies of compounds 32 and 36 were carried out against both $h$ CA IX and $h$ CA XII. By using BioSolveIT's SeeSAR software, further studies to provide visual clues to binding affinity indicate that the structural elements that are responsible for this were also studied. The binding of these compounds with hCA IX was highly favorable (as expected) and in agreement with the experimental data.
\end{abstract}

\section{Introduction}

Carbonic anhydrases (CAs and EC 4.2.1.1) are the $\mathrm{Zn}^{2+}$ containing metalloenzyme, belong to the superfamily of enzymes, and are found in all life kingdoms. CAs belong to seven different genetic families, sharing the common mission of catalyzing the reversible hydration of $\mathrm{CO}_{2}$ to carbonate and proton [1]. In addition to $\mathrm{CO}_{2}$ regulation, they are also responsible for lipogenesis, gluconeogenesis, and ureagenesis. Vertebrate carbonic anhydrases belong to the $\alpha$-CA class with 16 isozymes known so far. All these isozymes differ from one another due to their tissue specificity and localization in the cell. Many of them are cytosolic like CA I, CA II, CA III, CA VII, CA VIII, CA X, CA XI, and CA XIII. Some are membrane bound like CA IV, CA IX, CA XII, CA XIV, and CA XV. Some are mitochondrial like CAVA and CAVB, while CA VI is 
<smiles>CC(=O)Nc1nnc(S(N)(=O)=O)s1</smiles>

1<smiles>CC(=O)NC1SC(S(N)(=O)=O)=NN1C</smiles>

2

FIGURE 1

Table 1: Physical data of hydrazide (10-13).

Sr. no. Structure $\quad m$ mp $\left({ }^{\circ} \mathrm{C}\right) \quad R_{f}$ Yield (\%)

secreted into the cell's cytoplasm [2,3]. So far, nine CA isozymes were detected in the human central nervous system; it is believed that they are involved in many crucial functions, but the exact mechanism is not yet fully understood. Apart from their vital role in maintaining many important physiological processes, deregulation of carbonic anhydrases is also known to be associated with many pathologies, such as cerebral and retinal edema, glaucoma, epilepsy, stroke, retinitis pigmentosa, and growth of the tumor cells [2]. The overexpression of CA IX is lately been associated with the proliferation of the tumor cells providing a suitable environment for the tumor cells to grow; it has also been related to the poor response of patients to common chemotherapeutic reagents [4]. Acetazolamide (1) and methazolamide (2) are the clinically recognized carbonic anhydrase inhibitors (CAIs) and were tested on some forms of epilepsy in the 1970s (Figure 1). Lately, CAIs have been used in combination with other medicines in the treatment of obstructive sleep apnea; other CAIs of the brain isozymes are applied in the treatment of idiopathic intracranial hypertension (IIH), cerebral ischemia, neuropathic pain, and migraine [5].

As CAs are the zinc metalloenzymes, so, one of the classic types of carbonic anhydrase inhibitors is the zinc ion $\left(\mathrm{Zn}^{2+}\right)$ binders. These CAIs coordinate to the catalytically crucial $\mathrm{Zn}^{2+}$ from the enzyme site. During this inhibition type, $\mathrm{Zn}^{2+}$ could also be in tetrahedral or trigonal bipyramidal geometries. Sulfonamides, sulfamides, sulfamates, most anions,


22

23

24

25
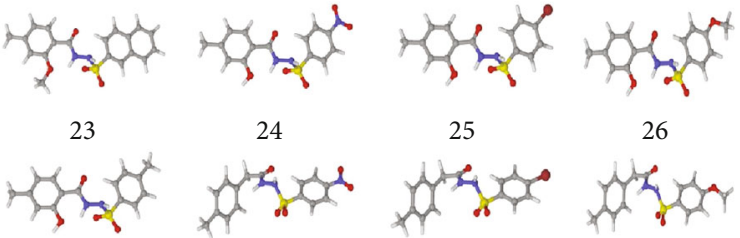

28

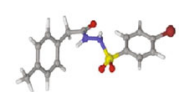

26

27

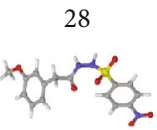

29
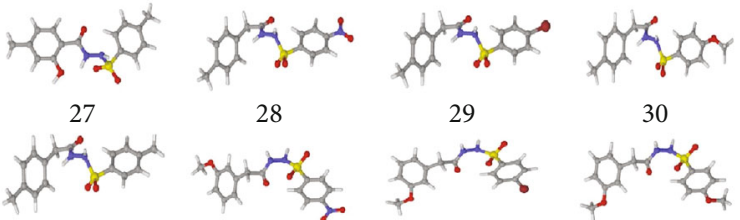

31

32

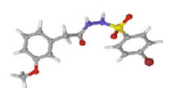

33

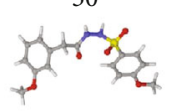

34



35



36

FIGURE 2: Optimized geometries of all the compounds under study (19-36) at PBE0-D3BJ/def2-TZVP/SMD ${ }_{\text {Solvent }}$ (Solvent $=\mathrm{CDCl}_{3}$, DMSO experimental solvent for NMR spectroscopy) level of the theory. In 3D models, grey color represents carbon, white represents hydrogens, yellow is for sulfur, red color is for oxygen, brown represents bromine, and blue color shows nitrogen atoms.

dithiocarbamates, carboxylates, and hydroxamates are the known CAIs that bind through this pathway [6]. Presence of the primary amino group make the sulphonamide excellent carbonic anhydrase inhibitor [7] but latest research reveals that secondary and tertiary sulphonamides also possess selective carbonic anhydrase inhibition activities [8-11].

Sulfonamides are considered a very important class of drugs; their major use is as carbonic anhydrase inhibitors and antibacterial agents [12]. The compounds that have another electron-withdrawing group or atom attached to the sulfanoyl group resulting in a compound with the - $\mathrm{NH}-\mathrm{SO}_{2}-$ $\mathrm{NH}_{2}$ group were found to be equipotent to free sulfonamides and sometimes stronger inhibitors [13]. This led us to the synthesis of some aryl- and acyl-substituted hydrazidesulfonamide hybrids and in vitro investigation of their carbonic anhydrase inhibition activities against CA II, CA IX, and CA XII. These isozymes were selected because CA II is the most active and abundant isozyme throughout the human body; the overexpression of CA IX and CA XII has always been related to the proliferation of the tumor cells [4]. NMR spectral data was verified by DFT studies. The molecular docking studies of the most potent derivatives and further confirmation by binding affinities studies were also carried out.

\section{Results and Discussion}

2.1. Chemistry. Synthesis of hydrazide-sulfonamide hybrids (19-36) was carried out starting from the synthesis of substituted hydrazides (10-13) [14]. For this reason, the methanolic solution of methyl esters (6-9) was refluxed with hydrazine monohydrate $64 \%$ to get respective hydrazides (10-13). Physical data of hydrazides (10-13) is presented in Table 1. Schematic representation of the reactions is presented in Scheme 1. 


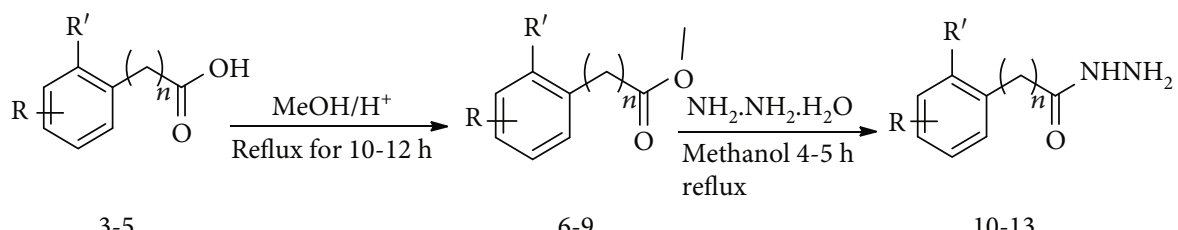

SCHeme 1: Synthesis of hydrazide (10-13).

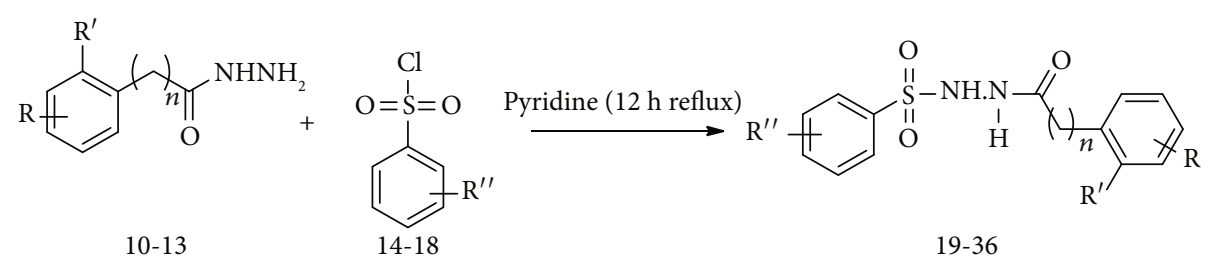

Scheme 2: Synthesis of hydrazide sulfonamide (19-36).



Figure 3: Possible binding mode of inhibitor 24 inside CA II active pocket.

Structural confirmation of hydrazide synthesis was done by using FT-IR and ${ }^{1} \mathrm{HNMR}$. In FT-IR spectrum, N-H stretching peak at $3018-3406 \mathrm{~cm}^{-1}$ and $\mathrm{NH}_{2}$ asymmetric stretch at $3229-3309 \mathrm{~cm}^{-1}$ while symmetric stretch at $3212-3329 \mathrm{~cm}^{-1}$ confirmed that hydrazide (10-13) has been synthesized. Further structural confirmation was done by the appearance of stretching peaks like $\mathrm{C}=\mathrm{O}$ at $1612 \mathrm{~cm}^{-1}$. C-H stretching peak at $3012 \mathrm{~cm}^{-1}$ and $\mathrm{C}=\mathrm{C}$ stretch at $1495 \mathrm{~cm}^{-1}$ of benzene ring also support the presence of functional groups of hydrazides. The presence of the methoxy group substitution in hydrazide 10 and 13 at the benzene ring showed asymmetric and symmetric stretching peaks at 1253 and $1155 \mathrm{~cm}^{-1}$, respectively. In the ${ }^{1} \mathrm{H}$ NMR spectrum of the hydrazides (10-13), a broad singlet of $\mathrm{NH}$ appeared at 6.73-9.02 ppm while a broad singlet of the $\mathrm{NH}_{2}$ group at 3.23-4.26 ppm confirmed the formation of compound (10-13). Two doublets at 8.07 and $7.96 \mathrm{ppm}$ and a singlet at $6.75 \mathrm{ppm}$ confirmed the presence of all aromatic signals [14].
For the synthesis of the compounds (19-36), hydrazide (10-13) $(0.5 \mathrm{mmol})$ was stirred with substituted benzenesulfonyl chloride (14-18) (0.5 mmol) in pyridine (Scheme 2). Physical data of the compounds (19-36) is presented in Table 2.

In the FT-IR spectrum, the appearance of NH stretching peak at $3321-3375 \mathrm{~cm}^{-1}$ and asymmetric and symmetric stretching peaks of $\mathrm{S}=\mathrm{O}$ at $1332-1387 \mathrm{~cm}^{-1}$ and 1189 $1195 \mathrm{~cm}^{-1}$, respectively, confirmed the hydrazidesulfonamide hybrid synthesis (19-36). Moreover, asymmetric and symmetric streching at $1553 \mathrm{~cm}^{-1}$ and $1376 \mathrm{~cm}^{-1}$ confirmed the nitro group, while C-H stretching peak at 3095$3132 \mathrm{~cm}^{-1}$ confirmed the aromatic rings. Stretching peak of $\mathrm{C}=\mathrm{O}$ at $1622-1670 \mathrm{~cm}^{-1}$, stretching peak of aliphatic $\mathrm{C}-\mathrm{H}$ at $3132 \mathrm{~cm}^{-1}$, and C-O stretching peak at $1230-1263 \mathrm{~cm}^{-1}$ were observed. The structures of all the synthesized compounds were confirmed by the ${ }^{1} \mathrm{HNMR}$ data. In the ${ }^{1} \mathrm{H}$ NMR data of hydrazide-sulfonamide hybrids (19-36), two singlets 
TABle 2: Physical data of sulfonamides (19-36).

\begin{tabular}{|c|c|c|c|c|}
\hline Sr. no. & Structure & $\mathrm{mp}\left({ }^{\circ} \mathrm{C}\right)$ & $R_{f}$ & Yield (\%) \\
\hline 19 & & $220-222$ & 0.5 & 89 \\
\hline 20 & & $168-169$ & 0.4 & 85 \\
\hline 21 & & $159-162$ & 0.3 & 83 \\
\hline 22 & & $161-163$ & 0.4 & 76 \\
\hline 23 & & $186-187$ & 0.4 & 79 \\
\hline 24 & & $211-213$ & 0.2 & 82 \\
\hline 25 & & $231-215$ & 0.3 & 81 \\
\hline 26 & & $168-169$ & 0.2 & 75 \\
\hline 27 & & $183-185$ & 0.3 & 85 \\
\hline
\end{tabular}


TABle 2: Continued.

\begin{tabular}{|c|c|c|c|c|}
\hline Sr. no. & Structure & $\mathrm{mp}\left({ }^{\circ} \mathrm{C}\right)$ & $R_{f}$ & Yield (\%) \\
\hline 28 & & $205-206$ & 0.5 & 85 \\
\hline 29 & & $156-157$ & 0.5 & 70 \\
\hline 30 & & $133-134$ & 0.3 & 82 \\
\hline 31 & & $143-144$ & 0.4 & 80 \\
\hline 32 & $\mathrm{~N}^{-3}$ & $158-159$ & 0.4 & 76 \\
\hline
\end{tabular}<smiles>COc1cccc(CC(=O)NNS(=O)(=O)c2ccc(Br)cc2)c1</smiles><smiles>COc1ccc(S(=O)(=O)NNC(=O)Cc2cccc(OC)c2)cc1</smiles> 
TABLE 2: Continued.

Sr. no. Structure

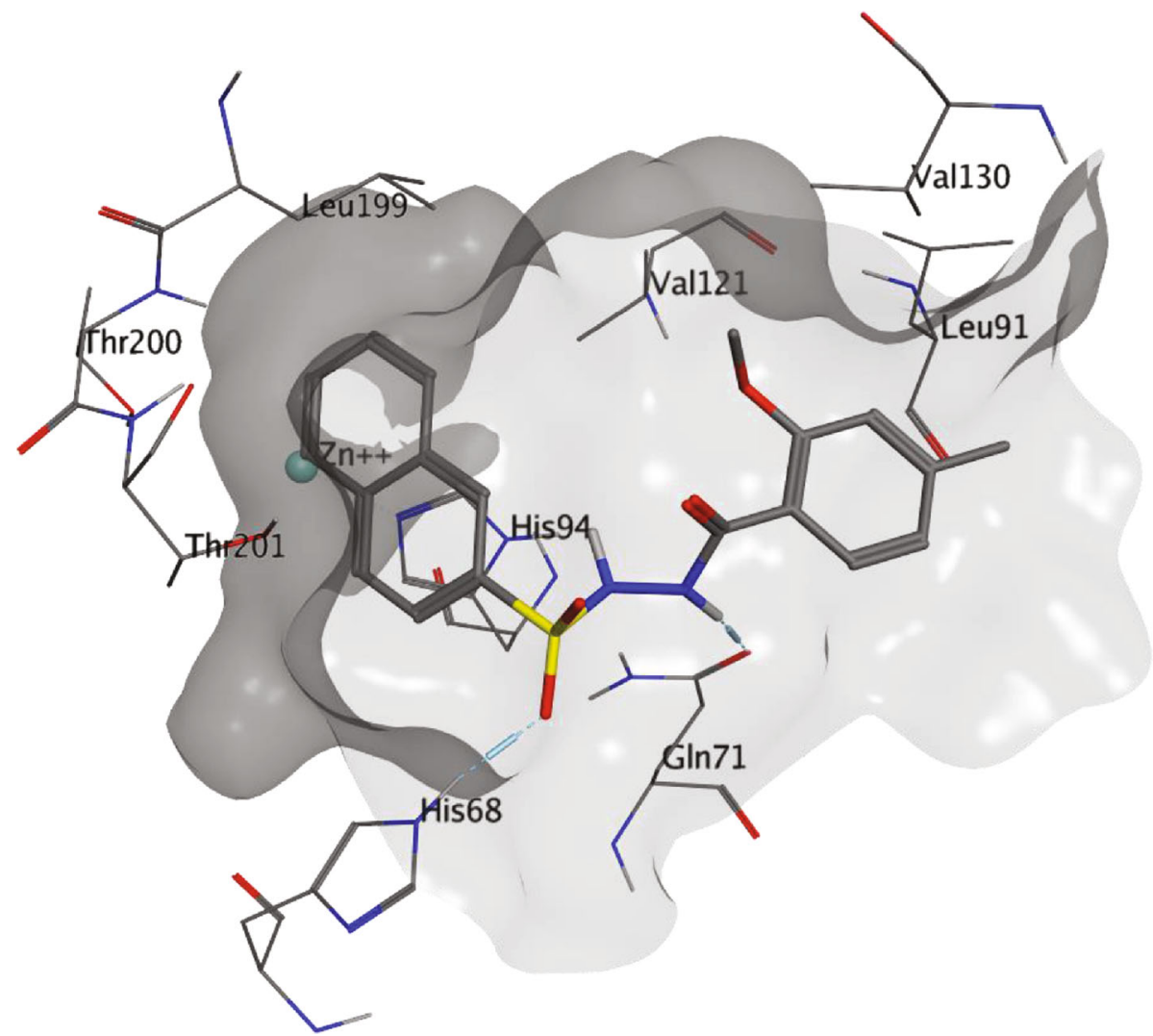

FIgure 4: Possible binding mode of the inhibitor 23 inside the CA IX active pocket.

appeared in the range of $10.45-10.61$ and $9.56-10.33 \mathrm{ppm}$ for $\mathrm{NH}$ groups which confirmed the formation of the product. Four doublets of all the aromatic protons of both benzene rings appeared in the aromatic region. The methyl group showed signal at 2.32-2.28 ppm [15]. To confirm the structures of the hydrazide-sulfonamide hybrids (19-36), the ${ }^{13} \mathrm{CNMR}$ spectra of the selected compounds were taken. The appearance of the signal at $164.3-164.8 \mathrm{ppm}$ for $\mathrm{S}=\mathrm{O}$ and 157.5-157.6 ppm for $\mathrm{C}=\mathrm{O}$ groups confirmed the synthesis of hydrazide-sulfonamide hybrids. To further justify the structures of hydrazide-sulfonamide hybrids EI-MS of the selected compounds were taken and the appearance of $[\mathrm{M}+1]$ molecular ions, peaks confirmed the structures of our desired products. To check the purity of the synthesized compounds, HPLC spectra of the selected compounds were taken in reverse phase in acetonitrile/water $(1: 1)$ mixture with a 10-11-minute retention time.
2.2. Computational Studies. All the synthesized compounds have been studied using the density functional theory (DFT) computations to gain an insight into their electronic structure and compute their NMR chemical shifts. The compounds have been subjected to geometry optimization using


chloroform) level of theory $[16,17]$ followed by their frequency calculations to verify that they are true minima on the potential energy surface (PES). Figure 2 shows their optimized geometries.

For organic chemists, nuclear magnetic resonance (NMR) is of prime importance and can be used as a vital technique to determine and verify the structures of synthesized molecules. DFT computations of NMR chemical shifts can yield an accurate NMR dataset that can be compared with the experimental data. All of the modeled compounds' NMR calculations have been performed on the same theoretical level as the 
TABLE 3: Comparison of experimental and computed NMR data for compound 19.



optimizations, and the results are compared with the experimental chemical shifts. Methanol and benzene have been employed as reference standards for $\mathrm{sp}^{3}$ and $\mathrm{sp}^{2}$ carbons due to their good and effective results, as formerly demonstrated by Perdew et al. [18]. The ${ }^{1} \mathrm{H}-\mathrm{NMR}$ data of compound 19 is given in Table 3. The supporting information contains a comparison of all of the other compounds. Furthermore, with a mean absolute error (MAE) of $0.19 \mathrm{ppm}$ only, it is evident that the NMR calculation methodology has worked really well. Consequently, some compounds' NMR data could not be obtained in a sufficient yield to get their precise experimental NMR; however, its accurate prediction from the computations can be utilized as a guide for the production of these compounds.

2.3. Carbonic Anhydrase Inhibition Studies. All the synthesized compounds were tested for their inhibition activity against the three isozymes of CAs, CA II, CA IX, and CA XII, using the optimized colorimetric method [19], and the results are shown in Table 4.

The synthesized compounds showed results against the three isozymes with relatively less $\mathrm{Ki}$ values against CA IX and CA XII. In the case of sulfonamide derivatives synthesized from salicylic acid hydrazide, the presence of the methoxy group at the orthoposition to the carbonyl group decreased the activity of compounds $19,20,21,22$, and 23 , while the unprotected hydroxyl group at the same position has clearly enhanced the activity of the compounds 24, 25, 26, and 27 against CA IX and CA XII [20]. In the case of phenylsubstituted acyl hydrazide derivatives, an enhancement of the activity against the three isozymes was observed in com-
TABLE 4: Ki values and inhibition percentages of the synthesized compounds against CA II, CA IX, and CA XII.

\begin{tabular}{lccc}
\hline Sr no. & CAII & CAIX & CAXII \\
& \multicolumn{2}{c}{ Ki $(\mu \mathrm{M} \pm$ SEM $) / \%$ inhibition } \\
\hline 19 & $0.68 \pm 0.02$ & $0.58 \pm 0.04$ & $44.4 \%$ \\
20 & $0.66 \pm 0.04$ & $0.56 \pm 0.05$ & $0.99 \pm 0.10$ \\
21 & $0.61 \pm 0.01$ & $0.19 \pm 0.02$ & $1.22 \pm 0.01$ \\
22 & $0.68 \pm 0.01$ & $1.04 \pm 0.38$ & $42.89 \%$ \\
23 & $0.94 \pm 0.02$ & $0.19 \pm 0.03$ & $0.75 \pm 0.07$ \\
24 & $0.34 \pm 0.01$ & $0.54 \pm 0.06$ & $0.52 \pm 0.04$ \\
25 & $0.91 \pm 0.02$ & $0.33 \pm 0.03$ & $0.35 \pm 0.04$ \\
26 & $0.96 \pm 0.09$ & $0.91 \pm 0.09$ & $0.58 \pm 0.04$ \\
27 & $1.11 \pm 0.04$ & $0.51 \pm 0.04$ & $0.43 \pm 0.08$ \\
28 & $0.46 \pm 0.01$ & $0.55 \pm 0.01$ & $1.02 \pm 0.08$ \\
29 & $0.73 \pm 0.02$ & $0.33 \pm 0.02$ & $0.55 \pm 0.01$ \\
30 & $0.74 \pm 0.04$ & $0.33 \pm 0.03$ & $0.13 \pm 0.01$ \\
31 & $0.67 \pm 0.01$ & $0.29 \pm 0.02$ & $0.40 \pm 0.09$ \\
32 & $0.67 \pm 0.06$ & $0.32 \pm 0.01$ & $49.25 \%$ \\
33 & $0.68 \pm 0.05$ & $0.39 \pm 0.03$ & $0.17 \pm 0.01$ \\
34 & $1.81 \pm 0.03$ & $0.65 \pm 0.03$ & $0.22 \pm 0.06$ \\
35 & $3.20 \pm 0.14$ & $1.18 \pm 0.04$ & $0.34 \pm 0.01$ \\
36 & $0.92 \pm 0.10$ & $0.60 \pm 0.01$ & $48.88 \%$ \\
Acetazolamide & $0.31 \pm 0.03$ & $0.30 \pm 0.01$ & $0.20 \pm 0.02$ \\
\hline & & &
\end{tabular}




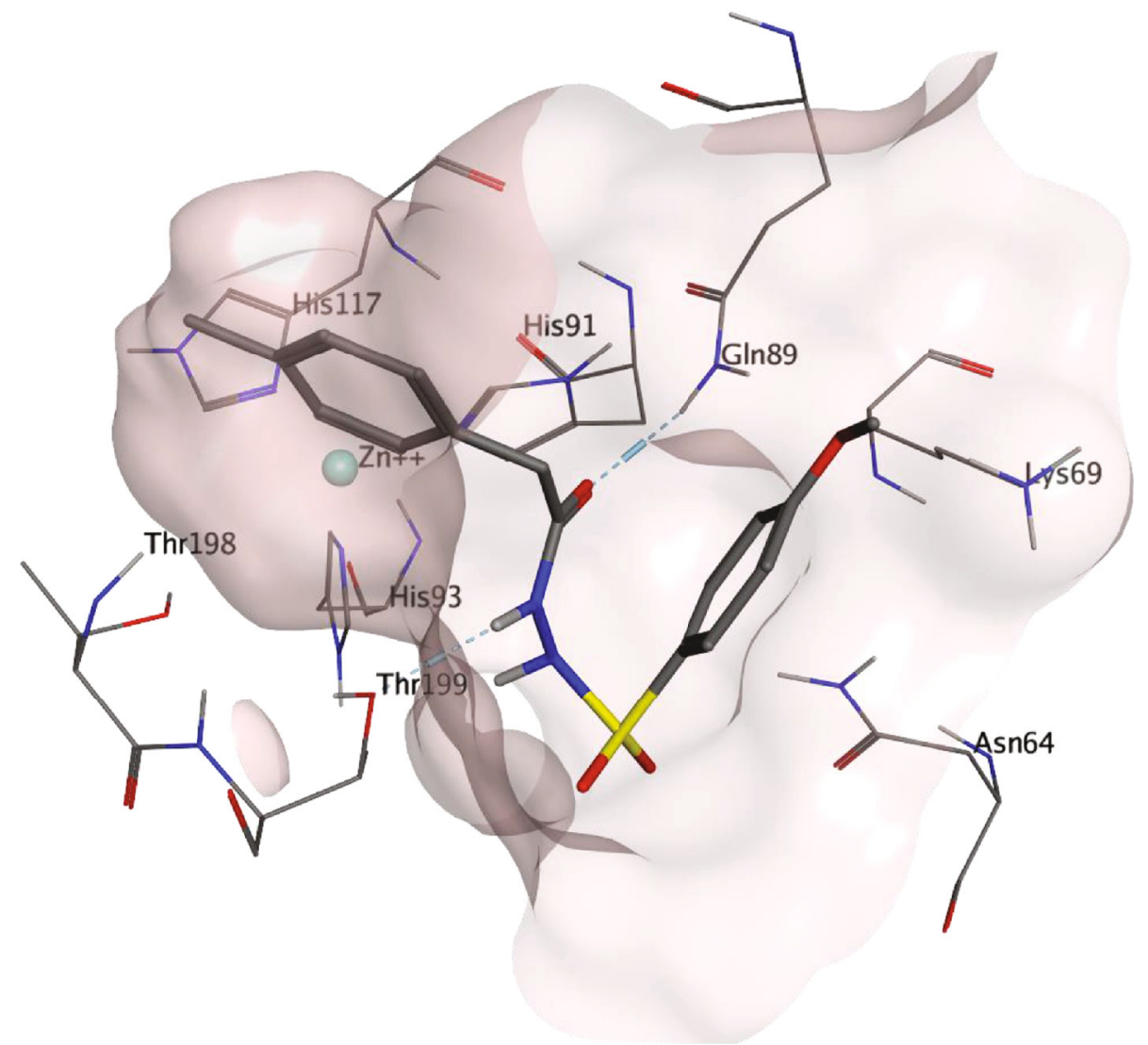

FIgURe 5: Possible binding mode of the inhibitor 30 inside the CA XII active pocket.

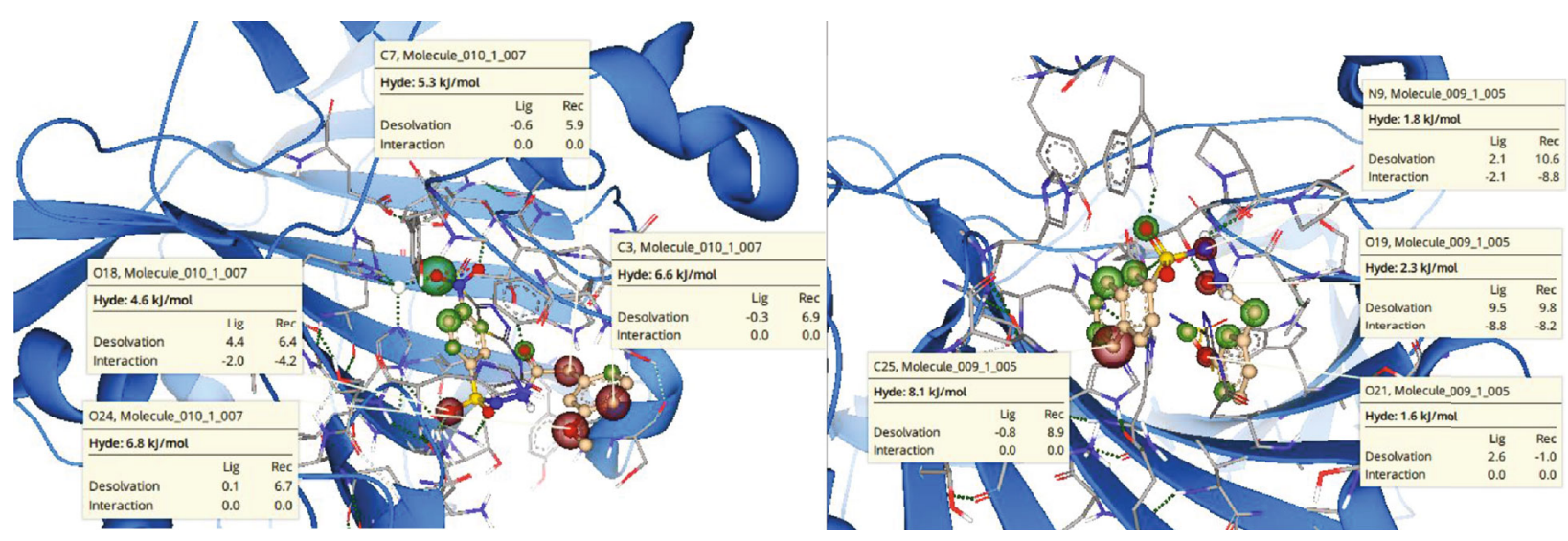

FIGURE 6: SeeSAR analysis (visual assessment of binding affinity) for compound 32 (a) and compound 36 (b) (selective hCA IX inhibitors over hCA XII) docked against hCA XII. The structural elements responsible for the favorable contribution to the overall binding affinity are shown in green coronas; the greater the sphere of the corona, the greater is the contribution. Similarly, the structural elements contributing unfavorably to the overall binding are shown in red coronas. The structural elements that are not contributing either favorably or unfavorably are not colored.

pounds $28,29,30$, and 31 . While for the compounds having 3 methoxyphenyl acyl derivatives, 32, 33, 34, 35, and 36 lead to variation between the three isozymes and the enhancement or decrease in the activity of the compound depended on other substituents coming from phenyl sulfonyl chloride part [21].

Substitution of the benzene ring containing the sulfonamide moiety with a methoxy and one more benzene greatly enhances the activity of compounds 21 and 23 , respectively, against CA IX, also seen in $\mathbf{3 0}$. The presence of a nitro group at this position enhances the activity of the compounds against CA II as seen in compounds 19, 24, 28, and 32 . Meanwhile, less effect of this group was observed within the activity of the compounds against CA IX and reduction in the activity of these compounds against CA XII. The presence of a bromide at this position showed variation depending of the substituents in the other benzene ring. Studies 


\begin{tabular}{|c|c|c|c|c|c|}
\hline & 1 & 11 & 21 & 31 & 41 \\
\hline $\begin{array}{l}\text { RMSD: ca } \\
\text { 6g9u hCA IX 1.75A.pdb, chain A } \\
\text { 1jd0 hCA XII-D...ep.pdb, chain A } \\
\text { 4qiy hCA II -D...ep.pdb, chain A }\end{array}$ & $\begin{array}{l}18 \\
2 \text { AS } \\
1\end{array}$ & $\begin{array}{l}\dot{\mathrm{G}} \dot{\mathrm{D}} \dot{\mathrm{E}} \dot{\mathrm{N}} \mathrm{S} \dot{\mathrm{S}} \mathrm{R} \\
\mathrm{K} H \mathrm{~N} \\
\mathrm{~K}\end{array}$ & $\begin{array}{l}\text { VSPACAGRFQ } \\
\text { KYPSCGGLLQ } \\
\text { DFP IAKGERQ }\end{array}$ & 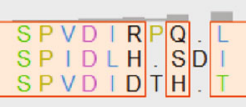 & $\begin{array}{l}\text { AAFSPALRPL } \\
L Q Y D A S L T P L \\
A K Y D P S L K P L \\
\end{array}$ \\
\hline RMSD: ca & 51 & 61 & 71 & & \\
\hline $\begin{array}{l}6 \text { g9u hCA IX 1.75A.pdb, chain A } \\
1 \text { jd0 hCA XII-D...ep.pdb, chain A } \\
\text { 4qiy hCA II -D...ep.pdb, chain A }\end{array}$ & 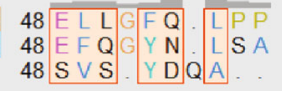 & $\begin{array}{l}L P E \\
N K Q \\
\cdots \\
\cdots\end{array}$ & $\begin{array}{l}\text { NGHSVQLTLP } \\
\text { NGHSVKLNLP } \\
\text { NGHAFNVEFD }\end{array}$ & 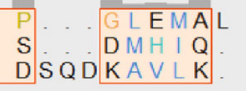 &  \\
\hline RMSD: ca & 101 & 111 & 121 & 131 & 141 \\
\hline $\begin{array}{l}\text { 6g9u hCA IX 1.75A.pdb, chain A } \\
\text { 1jd0 hCA XII-D...ep.pdb, chain A } \\
\text { 4qiy hCA II -D...ep.pdb, chain A }\end{array}$ & 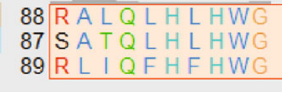 & 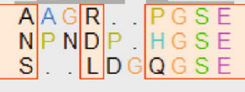 & $\begin{array}{l}\text { HTVEGHRFPA } \\
\text { HTVSGQHFAA } \\
\text { HTVDKKKYAA }\end{array}$ & $\begin{array}{l}\text { E I HVVHLSTA } \\
\text { ELH I VHYNSD } \\
\text { ELHLVHWNTK }\end{array}$ & $\begin{array}{l}F A R \vee D E A L G \\
Y P D A S T A S N \\
Y G D F G K A V Q\end{array}$ \\
\hline RMSD: ca & 151 & 161 & 171 & 181 & 191 \\
\hline $\begin{array}{l}\text { 6g9u hCA IX 1.75A.pdb, chain A } \\
\text { 1jd0 hCA XII-D...ep.pdb, chain A } \\
\text { 4qiy hCA II -D...ep.pdb, chain A }\end{array}$ & $\begin{array}{l}135 \text { RPGGLAVLAA } \\
136 \mathrm{KSEGLAVLAV} \\
136 \mathrm{QPDGLAVLG}\end{array}$ &  & $\begin{array}{l}\text { A Y EQ L LSRLE } \\
S Y D K I F S H L Q \\
G L Q K V \vee D V L D \\
\end{array}$ & $\begin{array}{l}E \text { I A E E SETQ } \\
H \vee K Y K G Q E A F \\
S \mid K T K G K S A D\end{array}$ & \begin{tabular}{l|l} 
VPGLD & $S A L L$ \\
$V P G F N$ & $E E L L$ \\
$F T N F D P R G L L$
\end{tabular} \\
\hline RMSD: ca & 201 & 211 & 221 & 231 & 241 \\
\hline $\begin{array}{l}\text { 6g9u hCA IX 1.75A.pdb, chain A } \\
\text { 1jd0 hCA XII-D...ep.pdb, chain A } \\
\text { 4qiy hCA II -D...ep.pdb, chain A }\end{array}$ & $\begin{array}{l}185 \text { PSDF SRYFQY } \\
185 \text { PER T A Y Y R Y } \\
185 \text { PES L . DYWTY }\end{array}$ & $\begin{array}{l}\text { EGSLTTPPCA } \\
R G S L T T P P C N \\
P G S L T T P P L L\end{array}$ & $\begin{array}{l}\text { Q GVIWTVFNQ } \\
P T V L W T V F R N \\
E C V T W I V L K E\end{array}$ & $\begin{array}{l}\text { TVMLSAKQLH } \\
P V Q \text { I SQEQLL } \\
P \mid S \vee S S E Q V L\end{array}$ & 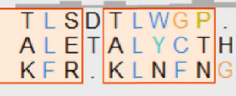 \\
\hline RMSD: ca & 251 & 261 & 271 & & \\
\hline $\begin{array}{l}\text { 6g9u hCA IX 1.75A.pdb, chain A } \\
\text { 1jd0 hCA XII-D...ep.pdb, chain A } \\
\text { 4qiy hCA II -D...ep.pdb, chain A }\end{array}$ & 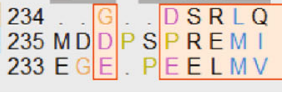 & $\begin{array}{l}\text { LNFRATQPLN } \\
\text { NNFRQVQKFD } \\
\text { DNWRPAQPLK }\end{array}$ & $\begin{array}{l}\text { GRVI EASFP. } \\
\text { ERLVYTSFSQ } \\
\text { NRQ I KASFK. }\end{array}$ & & \\
\hline
\end{tabular}

FIgURE 7: Sequence alignment of hCA II (4qiy), hCA IX (6g9u), and hCA XII (1jd0).

suggest that these compounds may play an important role as an anticancer agent with less side effect against the major off-target CA II which is readily available in a wide range of tissues and being the most active isozyme of the family. The presence of the specific functional groups enhanced the activity against the enzyme.

2.4. Molecular Docking Studies. The carbonic anhydrase isozymes (II, IX, and XII) selected for docking studies contained different sulfonamide inhibitors cocrystallized in the active pocket. These cocrystallized inhibitors were selected as reference for docking, and the docking protocol was validated after successfully reproducing the cocrystallized poses. The calculated RMSD values for reference ligands of CA II, CA IX, and CA XII were $0.90,0.83$, and $1.19 \AA$, respectively. The HYDE assessment shows a binding-free energy of -41 , -36 , and $-23 \mathrm{KJmol}^{-1}$, respectively.

Compound 24 was docked inside the active pocket of CA II with a FlexX score of -23 and HYDE score of $-18 \mathrm{KJmol}^{-1}$ (Figure 3). Similar to the reference cocrystallized ligand, inhibitor $\mathbf{2 4}$ forms hydrogen bonding interaction with residue Gln92 and a metal ion interaction with $\mathrm{Zn}^{+2}$ ion in the active pocket. Additionally, the residue Asn67 was found to form two hydrogen bonds with the carboxyl and amino group of compound 24. Likewise, the hydrophobic interactions in reference cocrystallized ligand the inhibitor $\mathbf{2 4}$ shows hydrophobic interactions with Gln92, His94, and Val121. Additionally, hydrophobic interactions with Leu60 and Asn67 were also observed.

The inhibitor 23 (Figure 4) was found to dock inside the CA IX active pocket with a FlexX score of -24 and binding affinity (HYDE score) of $-18 \mathrm{KJmol}^{-1}$. Similar to the reference ligand, inhibitor $\mathbf{2 3}$ was found to form hydrogen bonding interaction with the amino group of the residue Gln92. Unlike the reference ligand, no metal ion interaction was found due to the bulky naphthalene group in inhibitor 23. However, the sulfonamide group of the inhibitor adjacent to the naphthalene group was found to form hydrogen bonding interaction with residue His68. Additionally, the residue Gln71 was also found to form two hydrogen bonding interactions with amino groups of the inhibitor 23. Similar to the reference ligand, inhibitor $\mathbf{2 3}$ was found to form hydrophobic interactions with His94, Val130, Leu134, and Leu199. Additionally, several other hydrophobic interactions of inhibitor $\mathbf{2 3}$ with residues Leu91, Gln92, Thr201, and Val121 were also found.

Docking of the inhibitor 30 (Figure 5) inside the CA XII revealed a FlexX docking score of -19 and binding affinity of $-18 \mathrm{KJmol}^{-1}$. The inhibitor 30 was observed to form hydrogen bonding interaction with residues Lys69, Gln89, and Thr199. Interaction with residue Thr199 was also found in the case of cocrystallized sulfonamide inhibitor in the active pocket of CA XII. Unlike the cocrystallized inhibitor's sulfonamide group interaction with $\mathrm{Zn}^{+2}$ ions in the active site, no such interaction was found in the case of inhibitor $\mathbf{3 0}$ due to methoxy substitution adjacent to its sulfonamide group. The residues Asn64, Lys69, Gln89, Val119, Val141, Leu197, Thr199, and Val206 were observed to form hydrophobic interactions and pocket lining of inhibitor $\mathbf{3 0}$.

2.5. Investigating Selective Binding of 32 and 36 to $h C A I X$ over $h C A X I I$. Among the entire series, only compounds 22, 32, and 36 were highly selective inhibitors of hCA IX and did not inhibit hCA XII ( $<50 \%$ inhibition). We wanted to investigate why binding of these compounds to hCA XII is poor. For this purpose, the compounds $\mathbf{3 2}$ and $\mathbf{3 6}$ were docked against both hCA IX and hCA XII. Binding of these compounds with hCA IX was highly favorable (as expected) and in agreement with the experimental data. 
BioSolveIT's SeeSAR software [22, 23] provides visual clues to binding affinity (whether favorable or unfavorable) and also indicates the structural elements that are responsible for this. The SeeSAR analysis of compounds 32 and 36 are given in Figure 6. For compounds 32 and 36, most of the binding modes indicated highly unfavorable binding.

For compound 32 (Figure 6(a)), four structural elements were found to be highly unfavorable. One of oxygen atom of the sulfonamide group, the oxygen atom of the methoxy group, the carbon atom next to the carbon atom to which methoxy group is attached, and the carbon atom adjacent to the carbonyl group. With the exception of sulfonamide oxygen (that is involved in hydrogen bond formation with Asn62), other atoms (mentioned above) had a very high desolvation energy that had not been compensated by hydrogen bond formation. If the orientation of the inhibitor was such that result in some nonbonded interactions, the penalty on high desolvation energy would have been compensated, which is not the case; this may explain why binding of these molecules is inefficient. Similarly, for compound 36 (Figure 6(b)), four structural elements were found to be highly unfavorable. The sulfonamide $\mathrm{NH}$ and oxygen atom of the carbonyl group were contributing unfavorably because of high desolvation energy, although some of the unfavorable, high energy is compensated in part by the presence of hydrogen bonds that - $\mathrm{NH}$ is making with Pro201 and $-\mathrm{C}=\mathrm{O}$ with Thr200; it is not enough and the overall contribution is still somewhat unfavorable. The other two unfavorable structural elements are the oxygen atom of the methoxy group and carbon atom (C25) of the naphthyl group. Both have high desolvation energies that has not been compensated by the formation of any nonbonded interaction (Figure 7).

\section{Conclusions}

A series of sulfonamide-hydrazide hybrids of aryl and phenyl acetyl hydrazides (19-36) were synthesized and tested for their role as future anticancer agents with less side effects against CA II (major target), CA IX, and CA XII isozymes of carbonic anhydrase. It was found that substitution of the aromatic group has a significant role in determining the structure activity relationship studies. In the case of aryl substation when the 2-OH group was free, an enhanced activity was observed as compared to the compounds having substituted $\mathrm{OH}$ group with OMe. In the case of acetyl-substituted sulfonamidehydrazide hybrids, the addition of $\mathrm{CH}_{2}$ group enhances the activity as compared to the aryl group with one carbon. By using BioSolveIT's SeeSAR software, further studies to provide visual clues to binding affinity indicates that the structural elements that are responsible for this were also studied. Among the entire series, only compounds 22, 32, and 36 were highly selective inhibitors of hCA IX and did not inhibit hCA XII ( $<50 \%$ inhibition). We wanted to investigate why binding of these compounds to hCA XII is poor. For this purpose, compounds 32 and 36 were docked against both hCA IX and hCA XII. Binding of these compounds with hCA IX was highly favorable (as expected) and in agreement with the experimental data.

\section{Methodology}

4.1. General Procedure for the Synthesis of Ester (6-9). Substituted benzoic acid and phenyl acetic acids were refluxed with excess of methanol in the presence of sulfuric acid as catalyst to get methoxy esters (6-9) [14, 24].

(i) Methyl 2-Methoxy-4-methylbenzoate 6<smiles>COC(=O)c1ccc(C)cc1OC</smiles>

Yield: $88 \% ; R_{f}=(n-$ hexane $:$ EtOAc $=6: 4) 0.6$; mp (oil) [24].

(ii) Methyl 2-Hydroxy-4-methylbenzoate 7<smiles>COC(=O)c1ccc(C)cc1O</smiles>

Yield: $92 \% ; R_{f}=.(n-$ hexane $:$ EtOAc. $=7: 3) 0.8$; $\mathrm{mp}$ (oil) [24].

(iii) Methyl 2-(p-Tolyl)acetate (8)

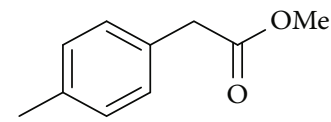

Yield: $87 \% ; R_{f}=(n-$ hexane : EtOAc. $=4: 1) 0.8$; bp. $\left({ }^{\circ} \mathrm{C}\right)$; oil [24].

(iv) Methyl 2-(3-Methoxyphenyl)acetate (9)<smiles>COC(=O)Cc1cccc(OC)c1</smiles>

Yield: $80 \% ; R_{f}=(n-$ hexane $:$ EtOAc. $=4: 1) 0.7$; bp $\left({ }^{\circ} \mathrm{C}\right)$; oil [24].

(v) General Procedure for the Synthesis of Hydrazides (10-13)

The alcoholic solution of methyl esters (6-9) were refluxed with the hydrazine monohydrate for 4-5 hours to get hydrazides (10-13). The solid obtained was purified by recrystallization using appropriate solvent $[14,24]$.

(i) 2-Methoxy-4-methylbenzohydrazide (10)<smiles>COc1cc(C)ccc1C(=O)NN</smiles>

Yield: $92 \% ; \quad R_{f}=(n-$ hexane $:$ EtOAc $=3: 2) 0.2$; mp. $\left(109-110^{\circ} \mathrm{C}\right)[24]$. 
(ii) 2-Hydoxy-4-methylbenzohydrazide (11)<smiles>Cc1ccc(C(=O)NN)c(O)c1</smiles>

Yield: $77 \% ; \quad R_{f}=(n-$ hexane $:$ EtOAc $=3: 2) 0.2$; mp. Melt with decompose [24].

(iii) 2-( $p$-Tolyl)acetohydrazide (12)<smiles>Cc1ccc(CC(=O)NN)cc1</smiles>

Yield: $85 \% ; R_{f}=(n-$ hexane $:$ EtOAc. $=3: 2)$; mp. $\left(153-154^{\circ} \mathrm{C}\right)[24]$.

(iv) 2-(3-Methoxyphenyl)acetohydrazide (13)<smiles>COc1cccc(CC(=O)NN)c1</smiles>

Yield: $82 \% ; R_{f}=(n-$ hexane $:$ EtOAc. $=3: 2) 0.2$; $\mathrm{mp} .\left(95-96^{\circ} \mathrm{C}\right)[24]$.

(v) General Procedure for the Synthesis of Hydrazide Sulfonamide (19-36)

Acyl- and aryl-substituted hydrazides (10-13) were stirred at room temperature with substituted sulfonyl chloride (14-18) in the presence of pyridine. After overnight stirring, solid product precipitated in the flask which was neutralized with dilute $\mathrm{HCl}$ to get rid of pyridine as pyridinium chloride. The solid obtained was filtered, washed with cold water, and recrystallized with appropriate solvent to purify the final product (19-36) [15].

(i) $N^{\prime}$-(2-Methoxy-4-methylbenzoyl)-4-nitrobenzenesulfonohydrazide (19)<smiles>COc1cc(C)ccc1C(=O)NNS(=O)(=O)c1ccc([N+](=O)[O-])cc1</smiles>

Yield: $89 \% ; R_{f}=(n-$ hexane $:$ EtOAc $=3: 2) 0.5$; $\mathrm{mp} .\left(220-222^{\circ} \mathrm{C}\right)$; HPLC purity $=96.1 \%(\mathrm{C} 18 \mathrm{RP}$, $\left.\mathrm{CH}_{3} \mathrm{CN} / \mathrm{H}_{2} \mathrm{O}-1: 1\right), \mathrm{TR}=11.1 \mathrm{~min}, \mathrm{FT}-\mathrm{IR}\left(\overline{\mathrm{v}}, \mathrm{cm}^{-1}\right)$ : 3321, 3149, 2817, 1664 (C=O), $1541\left(\mathrm{NO}_{2}\right), 1403$, $1380,1262,1181 ;{ }^{1} \mathrm{H}$ NMR $\left(400 \mathrm{MHz}, \mathrm{DMSO}-d_{6}\right)$ $(\delta, \mathrm{ppm}): 10.46(\mathrm{~s}, 1 \mathrm{H}, \mathrm{NH}), 10.21(\mathrm{~s}, 1 \mathrm{H}, \mathrm{NH})$, $8.39\left(\mathrm{~d}, J=8.1 \mathrm{~Hz}, 2 \mathrm{H}_{\mathrm{Ar}}\right), 8.09(\mathrm{~d}, J=8.8 \mathrm{~Hz}$, $\left.2 \mathrm{H}_{\mathrm{Ar}}\right), 7.26\left(\mathrm{~d}, J=7.7 \mathrm{~Hz}, 1 \mathrm{H}_{\mathrm{Ar}}\right), 6.92\left(\mathrm{~s}, 1 \mathrm{H}_{\mathrm{Ar}}\right)$, $6.78\left(\mathrm{~d}, J=7.7 \mathrm{~Hz}, 1 \mathrm{H}_{\mathrm{Ar}}\right), 3.80\left(\mathrm{~s}, 3 \mathrm{H}, \mathrm{OCH}_{3}\right)$, $2.32\left(\mathrm{~s}, 3 \mathrm{H}, \mathrm{CH}_{3}\right),{ }^{13} \mathrm{C}-\mathrm{NMR}(100 \mathrm{MHz}, \mathrm{DMSO}-$ $\left.d_{6}\right): \delta(\mathrm{ppm}) 165.0,156.9,149.9,145.2,143.1$, 129.9, 128.9, 125.1, 124.1, 121.0, 118.7, 55.8, 21.3, ESI-MS: $\mathrm{C}_{15} \mathrm{H}_{15} \mathrm{~N}_{3} \mathrm{O}_{6} \mathrm{~S}[\mathrm{M}+1] 366.2$.

(ii) 4-Bromo- $N^{\prime}$-(2-methoxy-4-methylbenzoyl)benzenesulfonohydrazide (20)<smiles>COc1cc(C)ccc1C(=O)NNS(=O)(=O)c1ccc(Br)cc1</smiles>

Yield: $85 \% ; \quad R_{f}=(n-$ hexane $:$ EtOAc. $=3: 2)$ 0.4 ; mp. $\quad\left(168-169^{\circ} \mathrm{C}\right) ; \quad$ HPLC purity $=91.8 \%$ (C18 RP, $\left.\mathrm{CH}_{3} \mathrm{CN} / \mathrm{H}_{2} \mathrm{O}-1: 1\right), \mathrm{TR}=10.1 \mathrm{~min}, \mathrm{FT}-$ IR $\left(\bar{v}, \mathrm{~cm}^{-1}\right)$ : 3321, 3095 (aromatic CH), 2887, $1622(\mathrm{C}=\mathrm{O}), 1375,1263,1198 ;{ }^{1} \mathrm{H}$ NMR (400 $\left.\left.\mathrm{MHz}, \mathrm{CDCl}_{3}\right)(\delta, \mathrm{ppm})\right): 9.56(\mathrm{~s}, 2 \mathrm{H}, \mathrm{NH}), 7.77$ $\left(\mathrm{dt}, J=8.6,2.3 \mathrm{~Hz}, 2 \mathrm{H}_{\mathrm{Ar}}\right), 7.72(\mathrm{~d}, J=7.9 \mathrm{~Hz}$, $\left.1 \mathrm{H}_{\mathrm{Ar}}\right), 7.59\left(\mathrm{dt}, J=8.6,2.3 \mathrm{~Hz}, 2 \mathrm{H}_{\mathrm{Ar}}\right), 6.86(\mathrm{~d}$, $\left.J=8.0 \mathrm{~Hz}, 1 \mathrm{H}_{\mathrm{Ar}}\right), 6.81\left(\mathrm{~s}, 1 \mathrm{H}_{\mathrm{Ar}}\right), 4.03(\mathrm{~s}, 3 \mathrm{H}$, $\left.\mathrm{OCH}_{3}\right), 2.41\left(\mathrm{~s}, 3 \mathrm{H}, \mathrm{CH}_{3}\right),{ }^{13} \mathrm{C} \mathrm{NMR}(100$ $\left.\mathrm{MHz}, \mathrm{CDCl}_{3}\right)(\delta, \mathrm{ppm}), 164.3,157.6,145.6$, $135.7,132.3,130.1,129.0,122.6,115.4,112.2$, $56.3,22.0$.

(iii) 4-Methoxy-N '-(2-methoxy-4-methylbenzoyl)benzenesulfono hydrazide (21)<smiles>COc1ccc(S(=O)(=O)NNC(=O)c2ccc(C)cc2OC)cc1</smiles>

Yield: $83 \% ; R_{f}=(n-$ hexane $:$ EtOAc $=3: 2) 0.3$; $\mathrm{mp}\left(159-162^{\circ} \mathrm{C}\right)$; FT-IR $\left(\overline{\mathrm{v}}, \mathrm{cm}^{-1}\right)$ : 3281, 3142 (aromatic $\mathrm{CH}), 2925,1696((\mathrm{C}=\mathrm{O}), 1358,1234,1184$; ${ }^{1} \mathrm{H}$ NMR (400 MHz, $\mathrm{CDCl}_{3}$ ) ( $\left.\delta, \mathrm{ppm}\right): 9.56$ (s, 2H, $\mathrm{NH}), 7.83\left(\mathrm{~d}, J=8.8 \mathrm{~Hz}, 2 \mathrm{H}_{\mathrm{Ar}}\right), 7.72(\mathrm{~d}, J=7.9$ $\left.\mathrm{Hz}, 1 \mathrm{H}_{\mathrm{Ar}}\right), 6.90\left(\mathrm{~d}, J=8.8 \mathrm{~Hz}, 2 \mathrm{H}_{\mathrm{Ar}}\right), 6.83(\mathrm{~d}, J$ $\left.=8.1 \mathrm{~Hz}, 1 \mathrm{H}_{\mathrm{Ar}}\right), 6.80\left(\mathrm{~s}, 1 \mathrm{H}_{\mathrm{Ar}}\right), 4.02(\mathrm{~s}, 3 \mathrm{H}$, $\left.\mathrm{OCH}_{3}\right), 3.83\left(\mathrm{~s}, 3 \mathrm{H}, \mathrm{OCH}_{3}\right), 2.40\left(\mathrm{~s}, 3 \mathrm{H}, \mathrm{CH}_{3}\right)$ ${ }^{13} \mathrm{C}$ NMR $\left(100 \mathrm{MHz}, \mathrm{CDCl}_{3}\right)(\delta, \mathrm{ppm}), 166.1$, $156.6,144.3,134.8,133.1,129.8,129.5,121.4$, $115.9,112.8,56.3,54.6,21.9$.

(iv) $N^{\prime}$-(2-Methoxy-4-methylbenzoyl)-4-methylbenzenesulfonohydrazide (22)<smiles>COc1cc(C)ccc1C(=O)NNS(=O)(=O)c1ccc(C)cc1</smiles>

Yield: $76 \% ; R_{f}=(n-$ hexane $:$ EtOAc $=3: 2) 0.4$; mp. (161-163 $\left.{ }^{\circ} \mathrm{C}\right)$; FT-IR ( $\left.\overline{\mathrm{v}}, \mathrm{cm}^{-1}\right): 3361,3137$ (aromatic $\mathrm{CH}), 2861,1679(\mathrm{C}=\mathrm{O}), 1332,1221,1178$; ${ }^{1} \mathrm{H}$ NMR (400 MHz, $\left.\mathrm{CDCl}_{3}\right)(\delta, \mathrm{ppm}): 7.87$ (d, $J$ 
$\left.=8.2 \mathrm{~Hz}, 2 \mathrm{H}_{\mathrm{Ar}}\right), 7.40\left(\mathrm{~d}, J=7.4 \mathrm{~Hz}, 2 \mathrm{H}_{\mathrm{Ar}}\right), 7.37(\mathrm{~d}$, $\left.J=8.1 \mathrm{~Hz}, 1 \mathrm{H}_{\mathrm{Ar}}\right), 6.78\left(\mathrm{~s}, 1 \mathrm{H}_{\mathrm{Ar}}\right), 6.75(\mathrm{~d}, J=8.1$ $\left.\mathrm{Hz}, 1 \mathrm{H}_{\mathrm{Ar}}\right), 3.88\left(\mathrm{~s}, 3 \mathrm{H}, \mathrm{OCH}_{3}\right), 2.44\left(\mathrm{~s}, 3 \mathrm{H}, \mathrm{CH}_{3}\right)$, $2.30\left(\mathrm{~s}, 3 \mathrm{H}, \mathrm{CH}_{3}\right)$.

(v) $N^{\prime}$-(2-Methoxy-4-methylbenzoyl)naphthalene2-sulfonohydrazide (23)<smiles>COc1cc(C)ccc1C(=O)NNS(=O)(=O)c1ccc2ccccc2c1</smiles>

Yield: 79\%; $R_{f}=(n-$ hexane : EtOAc $=3: 2) 0.4$; mp. $\left(186-187^{\circ} \mathrm{C}\right)$; HPLC purity $=97.42 \% \quad(\mathrm{C} 18$ $\left.\mathrm{RP}, \mathrm{CH}_{3} \mathrm{CN} / \mathrm{H}_{2} \mathrm{O}-1: 1\right), \mathrm{TR}=10.1 \mathrm{~min}, \mathrm{FT}-\mathrm{IR}(\overline{\mathrm{v}}$, $\mathrm{cm}^{-1}$ ): 3370, 3055 (aromatic $\left.\mathrm{CH}\right), 2805,1640(\mathrm{C}=$ O), 1360, 1290, 1196, 1187; ${ }^{1} \mathrm{H}$ NMR $(400 \mathrm{MHz}$, $\left.\mathrm{CDCl}_{3}\right)(\delta, \mathrm{ppm}): 9.61(\mathrm{~s}, 2 \mathrm{H}, \mathrm{NH}), 8.48\left(\mathrm{~s}, 1 \mathrm{H}_{\mathrm{Ar}}\right)$, 7.87-7.91 (m, $\left.4 \mathrm{H}_{\mathrm{Ar}}\right), 7.63(\mathrm{td}, J=7.0,0.9 \mathrm{~Hz}$, $\left.1 \mathrm{H}_{\mathrm{Ar}}\right), 7.54-7.58\left(\mathrm{~m}, 2 \mathrm{H}_{\mathrm{Ar}}\right), 6.78\left(\mathrm{~s}, 1 \mathrm{H}_{\mathrm{Ar}}\right), 6.74(\mathrm{~d}$, $\left.J=8.0 \mathrm{~Hz}, 1 \mathrm{H}_{\mathrm{Ar}}\right), 4.01\left(\mathrm{~s}, 3 \mathrm{H}, \mathrm{OCH}_{3}\right), 2.37(\mathrm{~s}, 3 \mathrm{H}$, $\mathrm{CH}_{3}$ ), ESI-MS: $\mathrm{C}_{19} \mathrm{H}_{18} \mathrm{~N}_{2} \mathrm{O}_{4} \mathrm{~S}[\mathrm{M}+1]$ 371.2.

(vi) $N^{\prime}$-(2-Hydroxy-4-methylbenzoyl)-4-nitrobenzenesulfonohydrazide (24)<smiles>Cc1ccc(C(=O)NNS(=O)(=O)c2ccc([N+](=O)[O-])cc2)c(O)c1</smiles>

Yield: $82 \% ; R_{f}=(n-$ hexane : EtOAc $=3: 2) 0.2$; mp. $\left(211-213^{\circ} \mathrm{C}\right)$; FT-IR $\left(\bar{v}, \mathrm{~cm}^{-1}\right)$ : 3365, 3132, 2805, $1670(\mathrm{C}=\mathrm{N}), 1553\left(\mathrm{NO}_{2}\right), 1376$ (nitro), 1387, 1230, 1189; ${ }^{1} \mathrm{H}$ NMR (400 MHz, DMSO- $d_{6}$ ) $(\delta, \mathrm{ppm}): 11.29$ (s, $1 \mathrm{H}, \mathrm{OH}), 10.61(\mathrm{~s}, 1 \mathrm{H}, \mathrm{NH})$, $10.52(\mathrm{~s}, 1 \mathrm{H}, \mathrm{NH}), 8.39\left(\mathrm{~d}, J=8.8 \mathrm{~Hz}, 2 \mathrm{H}_{\mathrm{Ar}}\right), 8.08$ $\left(\mathrm{d}, J=8.8 \mathrm{~Hz}, 2 \mathrm{H}_{\mathrm{Ar}}\right), 7.58\left(\mathrm{~d}, J=8.2 \mathrm{~Hz}, 1 \mathrm{H}_{\mathrm{Ar}}\right)$, $6.71\left(\mathrm{~d}, J=7.6 \mathrm{~Hz}, 1 \mathrm{H}_{\mathrm{Ar}}\right), 6.71\left(\mathrm{~s}, 1 \mathrm{H}_{\mathrm{Ar}}\right), 2.25(\mathrm{~s}$, $\left.3 \mathrm{H}, \mathrm{CH}_{3}\right)$.

(vii) 4-Bromo- $N$ '-(2-hydroxy-4-methylbenzoyl)benzenesulfonohydrazide (25)<smiles>Cc1ccc(C(=O)NNS(=O)(=O)c2ccc(Br)cc2)c(O)c1</smiles>

Yield: $81 \% ; R_{f}=(n-$ hexane $:$ EtOAc $=3: 2) 0.3$; $\mathrm{mp}\left(231-215^{\circ} \mathrm{C}\right)$; FT-IR $\left(\overline{\mathrm{v}}, \mathrm{cm}^{-1}\right)$ : 3357, 3087, 2809, 1656 (C=O), 1368, 1271, 1192; ${ }^{1} \mathrm{H}$ NMR $\left(400 \mathrm{MHz}, \mathrm{CDCl}_{3}\right)(\delta, \mathrm{ppm}): 10.50$ (bs, $1 \mathrm{H}$, $\mathrm{OH}), 7.78\left(\mathrm{~d}, J=7.6 \mathrm{~Hz}, 2 \mathrm{H}_{\mathrm{Ar}}\right), 7.62(\mathrm{~d}, J=8.5$ $\left.\mathrm{Hz}, 2 \mathrm{H}_{\mathrm{Ar}}\right), 7.33\left(\mathrm{~d}, J=8.1 \mathrm{~Hz}, 1 \mathrm{H}_{\mathrm{Ar}}\right), 6.78(\mathrm{~s}$, $\left.1 \mathrm{H}_{\mathrm{Ar}}\right), 6.72\left(\mathrm{~d}, J=8.0 \mathrm{~Hz}, 1 \mathrm{H}_{\mathrm{Ar}}\right), 2.19(\mathrm{~s}, 3 \mathrm{H}$, $\left.\mathrm{CH}_{3}\right)$. (viii) $N \quad$ '-(2-Hydroxy-4-methylbenzoyl)-4-methoxybenzenesulfono hydrazide (26)<smiles>COc1ccc(S(=O)(=O)NNC(=O)c2ccc(C)cc2O)cc1</smiles>

Yield: $75 \% ; \quad R_{f}=.(n-$ hexane $:$ EtOAc $=3: 2)$ 0.2; mp $\left(168-169^{\circ} \mathrm{C}\right)$; FT-IR $\left(\overline{\mathrm{v}}, \mathrm{cm}^{-1}\right): 3343,3028$, 2865, $1663(\mathrm{C}=\mathrm{O}), 1362,1199,1187 ;{ }^{1} \mathrm{H}$ NMR $\left(400 \mathrm{MHz}, \mathrm{CDCl}_{3}\right)(\delta, \mathrm{ppm}): 10.55$ (bs, $\left.1 \mathrm{H}, \mathrm{OH}\right)$, $7.85\left(\mathrm{~d}, J=8.5 \mathrm{~Hz}, 2 \mathrm{H}_{\mathrm{Ar}}\right), 7.74(\mathrm{~d}, J=7.9 \mathrm{~Hz}$, $\left.1 \mathrm{H}_{\mathrm{Ar}}\right), 6.93\left(\mathrm{~d}, J=8.5 \mathrm{~Hz}, 2 \mathrm{H}_{\mathrm{Ar}}\right), 6.87(\mathrm{~d}, J=8.1$ $\left.\mathrm{Hz}, 1 \mathrm{H}_{\mathrm{Ar}}\right), 6.79\left(\mathrm{~s}, 1 \mathrm{H}_{\mathrm{Ar}}\right), 3.86\left(\mathrm{~s}, 3 \mathrm{H}, \mathrm{OCH}_{3}\right)$, $2.42\left(\mathrm{~s}, 3 \mathrm{H}, \mathrm{CH}_{3}\right)$.

(ix) $N^{\prime}$-(2-Hydroxy-4-methylbenzoyl)-4-methylbenzenesulfonohydrazide (27)

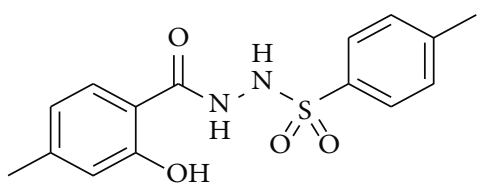

Yield: $85 \% ; R_{f}=(n-$ hexane $:$ EtOAc $=3: 2) 0.3$; mp. $\left(183-185^{\circ} \mathrm{C}\right)$; FT-IR $\left(\overline{\mathrm{v}}, \mathrm{cm}^{-1}\right): 3389,3012$ (aromatic CH), 2896, $1671(\mathrm{C}=\mathrm{O}), 1336,1231$, 1182; ${ }^{1} \mathrm{H}$ NMR $\left(400 \mathrm{MHz}, \mathrm{CDCl}_{3}\right)(\delta, \mathrm{ppm})$ : 10.56 (bs, $1 \mathrm{H}, \mathrm{OH}), 7.81$ (d, $J=8.2 \mathrm{~Hz}, 2 \mathrm{H}_{\mathrm{Ar}}$ ), $7.43\left(\mathrm{~d}, J=7.4 \mathrm{~Hz}, 2 \mathrm{H}_{\mathrm{Ar}}\right), 7.32(\mathrm{~d}, J=8.1 \mathrm{~Hz}$, $\left.1 \mathrm{H}_{\mathrm{Ar}}\right), 6.76\left(\mathrm{~s}, 1 \mathrm{H}_{\mathrm{Ar}}\right), 6.73\left(\mathrm{~d}, J=8.2 \mathrm{~Hz}, 1 \mathrm{H}_{\mathrm{Ar}}\right)$, $2.42\left(\mathrm{~s}, 3 \mathrm{H}, \mathrm{CH}_{3}\right), 2.34\left(\mathrm{~s}, 3 \mathrm{H}, \mathrm{CH}_{3}\right)$, ESI-MS: $\mathrm{C}_{15} \mathrm{H}_{16} \mathrm{~N}_{2} \mathrm{O}_{4} \mathrm{~S}[\mathrm{M}+1] 321.2$.

(x) 4-Nitro- $N^{\prime}$-(2-(p-tolyl)acetyl)benzenesulfonohydrazide (28)<smiles>Cc1ccc(CC(=O)NNS(=O)(=O)c2ccc([N+](=O)[O-])cc2)cc1</smiles>

Yield: $85 \% ; \quad R_{f} .=(n-$ hexane $:$ EtOAc. $=1: 1)$ 0.5; mp. $\left(205-206^{\circ} \mathrm{C}\right)$; FT-IR $\left(\bar{v}, \mathrm{~cm}^{-1}\right): 3375$, 3018 (aromatic CH), 2912, $1698(\mathrm{C}=\mathrm{O}), 1550$ (nitro asymmetric), 1385 (nitro symmetric), 1324, $1195 ;{ }^{1} \mathrm{H}$ NMR (400 MHz, DMSO- $\left.d_{6}\right)(\delta$, ppm): 10.45 (s, 1H, NH), 10.33 (s, 1H, NH), $8.18\left(\mathrm{~d}, J=8.8 \mathrm{~Hz}, 2 \mathrm{H}_{\mathrm{Ar}}\right), 7.90(\mathrm{~d}, J=8.8 \mathrm{~Hz}$, $\left.2 \mathrm{H}_{\mathrm{Ar}}\right), 7.06\left(\mathrm{~d}, J=7.6 \mathrm{~Hz}, 2 \mathrm{H}_{\mathrm{Ar}}\right), 6.97(\mathrm{~d}, J=8.0$ $\mathrm{Hz}, 2 \mathrm{H}_{\mathrm{Ar}}$ ), 3.22 (s, $2 \mathrm{H}, \mathrm{CH}_{2}$ ), 2.28 (s, 3H, $\mathrm{CH}_{3}$ ).

(xi) 4-Bromo- $N$ '-(2-(p-tolyl)acetyl)benzenesulfonohydrazide (29) 
<smiles>Cc1ccc(CC(=O)NNS(=O)(=O)c2ccc(Br)cc2)cc1</smiles>

Yield: $70 \% ; R_{f} .=.(n-$ hexane $:$ EtOAc. $=1: 1)$ 0.5 ; mp. $\left(156-157^{\circ} \mathrm{C}\right)$; FT-IR $\left(\bar{v}, \mathrm{~cm}^{-1}\right): 3360$, 3022 (aromatic CH), 2918, $1696(\mathrm{C}=\mathrm{O}), 1328$, 1195; ${ }^{1} \mathrm{H} \mathrm{NMR}\left(400 \mathrm{~Hz}, \mathrm{CDCl}_{3}\right)(\delta, \mathrm{ppm}): 7.99$ $\left(\mathrm{d}, \quad J=7.8 \mathrm{~Hz}, 2 \mathrm{H}_{\mathrm{Ar}}\right), \quad 7.62(\mathrm{~d}, \quad J=8.4 \mathrm{~Hz}$, $\left.2 \mathrm{H}_{\mathrm{Ar}}\right), 7.50\left(\mathrm{~d}, J=8.4 \mathrm{~Hz}, 2 \mathrm{H}_{\mathrm{Ar}}\right), 7.17(\mathrm{~d}, J=$ $7.7 \mathrm{~Hz}, 2 \mathrm{H}_{\mathrm{Ar}}$ ), 3.37 (s, $\left.2 \mathrm{H}, \mathrm{CH}_{2}\right), 2.40(\mathrm{~s}, 3 \mathrm{H}$, $\left.\mathrm{CH}_{3}\right)$.

(xii) 4-Methoxy-N '-(2-(p-tolyl)acetyl)benzenesulfonohydrazide (30)<smiles>COc1ccc(S(=O)(=O)NNC(=O)Cc2ccc(C)cc2)cc1</smiles>

Yield: $82 \% ; \quad R_{f} .=(n-$ hexane $:$ EtOAc. $=1: 1)$ 0.3 ; mp. $\left(133-134^{\circ} \mathrm{C}\right)$; FT-IR $\left(\bar{v}, \mathrm{~cm}^{-1}\right): 3354$ (NH), 3043, 2919, 1697 (C=O), 1327, 1191; ${ }^{1} \mathrm{H}$ NMR $\left(400 \mathrm{MHz}, \mathrm{CDCl}_{3}\right)(\delta, \mathrm{ppm}): 7.73$ (d, J $\left.=8.8 \mathrm{~Hz}, 2 \mathrm{H}_{\mathrm{Ar}}\right), 7.15\left(\mathrm{~d}, J=7.7 \mathrm{~Hz}, 2 \mathrm{H}_{\mathrm{Ar}}\right)$, $7.00\left(\mathrm{~d}, J=7.8 \mathrm{~Hz}, 2 \mathrm{H}_{\mathrm{Ar}}\right), 6.89(\mathrm{~d}, J=8.8 \mathrm{~Hz}$, $\left.2 \mathrm{H}_{\mathrm{Ar}}\right), 3.87\left(\mathrm{~s}, 3 \mathrm{H}, \mathrm{OCH}_{3}\right), 3.37\left(\mathrm{~s}, 2 \mathrm{H}, \mathrm{CH}_{2}\right)$, $2.37\left(\mathrm{~s}, 3 \mathrm{H}, \mathrm{CH}_{3}\right)$.

(xiii) 4-Methyl- $N^{\prime}$-(2-( $p$-tolyl)acetyl)benzenesulfonohydrazide (31)<smiles>Cc1ccc(CC(=O)NNS(=O)(=O)c2ccc(C)cc2)cc1</smiles>

Yield: $80 \% ; \quad R_{f} \cdot=(n-$ hexane $:$ EtOAc. $=1: 1)$ 0.4 ; mp. $\left(143-144^{\circ} \mathrm{C}\right)$; FT-IR $\left(\bar{v}, \mathrm{~cm}^{-1}\right): 3343$ (NH), 3043, 2965, $1692(\mathrm{C}=\mathrm{O}), 1328,1197 ;{ }^{1} \mathrm{H}$ NMR $\left(400 \mathrm{MHz}, \mathrm{CDCl}_{3}\right)(\delta, \mathrm{ppm}): 7.69$ (d, J $\left.=8.2 \mathrm{~Hz}, 2 \mathrm{H}_{\mathrm{Ar}}\right), 7.22\left(\mathrm{~d}, J=8.0 \mathrm{~Hz}, 2 \mathrm{H}_{\mathrm{Ar}}\right)$, $7.15\left(\mathrm{~d}, J=7.7 \mathrm{~Hz}, 2 \mathrm{H}_{\mathrm{Ar}}\right), 7.00(\mathrm{~d}, J=7 . \mathrm{Hz}$, $\left.2 \mathrm{H}_{\mathrm{Ar}}\right), 3.36\left(\mathrm{~s}, 2 \mathrm{H}, \mathrm{CH}_{2}\right), 2.42\left(\mathrm{~s}, 3 \mathrm{H}, \mathrm{CH}_{3}\right)$, $2.38\left(\mathrm{~s}, 3 \mathrm{H}, \mathrm{CH}_{3}\right)$.

(xiv) $N \quad$ '-(2-(3-Methoxyphenyl)acetyl)-4-nitrobenzenesulfonohydrazide (32)<smiles>COc1cccc(CC(=O)NNS(=O)(=O)c2ccc([N+](=O)[O-])cc2)c1</smiles>

Yield: $76 \% ; \quad R_{f} .=(n-$ hexane $:$ EtOAc. $=1: 1)$ 0.4 ; mp. $\left(158-159^{\circ} \mathrm{C}\right)$; FT-IR $\left(\overline{\mathrm{v}}, \mathrm{cm}^{-1}\right): 3360$ $(\mathrm{NH}), 3018,2912,1685(\mathrm{C}=\mathrm{O}), 1553$ (nitro asymmetric), 1390 (nitro symmetric), 1326, 1195, $1282 ;{ }^{1} \mathrm{H}$ NMR $\left(400 \mathrm{MHz}, \mathrm{DMSO}-d_{6}\right)(\delta, \mathrm{ppm})$ : 10.47 (d, 1H, NH), 10.36 (d, 1H, NH), 8.21 (d, J $\left.=8.8 \mathrm{~Hz}, 2 \mathrm{H}_{\mathrm{Ar}}\right), 7.90\left(\mathrm{~d}, J=8.8 \mathrm{~Hz}, 2 \mathrm{H}_{\mathrm{Ar}}\right), 7.18$ $\left(\mathrm{t}, J=7.8 \mathrm{~Hz}, 1 \mathrm{H}_{\mathrm{Ar}}\right), 6.80(\mathrm{dd}, J=8.1,2.2 \mathrm{~Hz}$, $\left.1 \mathrm{H}_{\mathrm{Ar}}\right), 6.69\left(\mathrm{~d}, J=7.5 \mathrm{~Hz}, 1 \mathrm{H}_{\mathrm{Ar}}\right), 6.64\left(\mathrm{~s}, 1 \mathrm{H}_{\mathrm{Ar}}\right)$, $3.71\left(\mathrm{~s}, 3 \mathrm{H}, \mathrm{OCH}_{3}\right), 3.26\left(\mathrm{~s}, 2 \mathrm{H}, \mathrm{CH}_{2}\right)$.

(xv) 4-Bromo-N '-(2-(3-methoxyphenyl)acetyl)benzenesulfonohydrazide (33)<smiles>COc1cccc(CC(=O)NNS(=O)(=O)c2ccc(Br)cc2)c1</smiles>

Yield: $80 \% ; \quad R_{f} .=(n-$ hexane $:$ EtOAc. $=1: 1)$ 0.4 ; mp. $\left(153-154^{\circ} \mathrm{C}\right)$; FT-IR $\left(\bar{v}, \mathrm{~cm}^{-1}\right): 3345$ $(\mathrm{NH}), 3018,2932,1697(\mathrm{C}=\mathrm{O}), 1345,1282$, $1195 ;{ }^{1} \mathrm{H}$ NMR $\left(400 \mathrm{MHz}, \mathrm{CDCl}_{3}\right)(\delta, \mathrm{ppm})$ : $7.63\left(\mathrm{t}, \quad J=8.4,1 \mathrm{H}_{\mathrm{Ar}}\right) 7.62 \quad(\mathrm{~d}, \quad J=8.4 \mathrm{~Hz}$, $\left.2 \mathrm{H}_{\mathrm{Ar}}\right), 7.53\left(\mathrm{~d}, J=8.4,2 \mathrm{H}_{\mathrm{Ar}}\right), 6.90(\mathrm{dd}, J=8.2$, $\left.1.8 \mathrm{~Hz}, 1 \mathrm{H}_{\mathrm{Ar}}\right), 6.70\left(\mathrm{~d}, J=7.16 \mathrm{~Hz}, 1 \mathrm{H}_{\mathrm{Ar}}\right), 6.66$ $\left(\mathrm{s}, 1 \mathrm{H}_{\mathrm{Ar}}\right), 3.84\left(\mathrm{~s}, 3 \mathrm{H}, \mathrm{OCH}_{3}\right), 3.38(\mathrm{~s}, 2 \mathrm{H}$, $\mathrm{CH}_{2}$ ).

(xvi) 4-Methoxy- $N^{\prime}$-(2-(3-methoxyphenyl)acetyl)benzenesulfonohydrazide (34)<smiles>COc1ccc(S(=O)(=O)NNC(=O)Cc2cccc(OC)c2)cc1</smiles>

Yield: $70 \% ; \quad R_{f} .=(n-$ hexane $:$ EtOAc. $=1: 1)$ 0.2 ; mp. $\left(146-147^{\circ} \mathrm{C}\right)$; FT-IR $\left(\bar{v}, \mathrm{~cm}^{-1}\right): 3364$ (NH), 3054, 2910, $1698(\mathrm{C}=\mathrm{O}), 1356,1195 ;{ }^{1} \mathrm{H}$ 
NMR (400 MHz, $\left.\mathrm{CDCl}_{3}\right)(\delta, \mathrm{ppm}): 9.85$ (bs, 2H, $\mathrm{NH})$, 7.71-7.75 (m, 2 $\left.\mathrm{H}_{\mathrm{Ar}}\right), 6.84-6.90\left(\mathrm{~m}, 4 \mathrm{H}_{\mathrm{Ar}}\right)$, $6.71\left(\mathrm{~d}, J=6.1 \mathrm{~Hz}, 1 \mathrm{H}_{\mathrm{Ar}}\right), 6.67\left(\mathrm{~s}, 1 \mathrm{H}_{\mathrm{Ar}}\right), 3.88(\mathrm{~s}$, $\left.3 \mathrm{H}, \mathrm{OCH}_{3}\right), 3.82\left(\mathrm{~s}, 3 \mathrm{H}, \mathrm{OCH}_{3}\right), 3.38(\mathrm{~s}, 2 \mathrm{H}$, $\mathrm{CH}_{2}$ ).

(xvii) $N$ '-(2-(3-Methoxyphenyl)acetyl)-4-methylbenzenesulfonohydrazide (35)<smiles>COc1cccc(CC(=O)NNS(=O)(=O)c2ccc(C)cc2)c1</smiles>

Yield: $87 \% ; \quad R_{f} .=(n-$ hexane $:$ EtOAc. $=1: 1)$ 0.3 ; mp. (143-144 $\left.{ }^{\circ} \mathrm{C}\right)$; FT-IR $\left(\overline{\mathrm{v}}, \mathrm{cm}^{-1}\right): 3342$ $(\mathrm{NH}), 3034,2912,1697(\mathrm{C}=\mathrm{O}), 1388,1196$, 1282; ${ }^{1} \mathrm{H} \mathrm{NMR}\left(400 \mathrm{MHz}, \mathrm{CDCl}_{3}\right)(\delta, \mathrm{ppm})$ : $7.79\left(\mathrm{~d}, J=7.6 \mathrm{~Hz}, 2 \mathrm{H}_{\mathrm{Ar}}\right), 7.68(\mathrm{~d}, J=7.6 \mathrm{~Hz}$, $\left.2 \mathrm{H}_{\mathrm{Ar}}\right), 7.23\left(\mathrm{t}, J=7.6 \mathrm{~Hz}, 1 \mathrm{H}_{\mathrm{Ar}}\right), 6.87(\mathrm{~d}, J=7.6$ $\left.\mathrm{Hz}, 2 \mathrm{H}_{\mathrm{Ar}}\right), 6.70\left(\mathrm{~d}, J=6.8 \mathrm{~Hz}, 2 \mathrm{H}_{\mathrm{Ar}}\right), 6.67$ (s, $\left.1 \mathrm{H}_{\mathrm{Ar}}\right), 3.82\left(\mathrm{~s}, 3 \mathrm{H}, \mathrm{OCH}_{3}\right), 3.37\left(\mathrm{~s}, 2 \mathrm{H}, \mathrm{CH}_{2}\right)$ $2.42\left(\mathrm{~s}, 3 \mathrm{H}, \mathrm{CH}_{3}\right)$.

(xviii) $N$ '-(2-(3-Methoxyphenyl)acetyl)naphthalene-2sulfonohydrazide (36)<smiles>COc1cccc(CC(=O)NNS(=O)(=O)c2ccc3ccccc3c2)c1</smiles>

Yield: $84 \% ; \quad R_{f} .=(n-$ hexane $:$ EtOAc. $=1: 1)$ 0.5 ; mp. $\left(139-141^{\circ} \mathrm{C}\right)$; FT-IR $\left(\overline{\mathrm{v}}, \mathrm{cm}^{-1}\right): 3358$ $(\mathrm{NH}), 3018,2912,1695(\mathrm{C}=\mathrm{O}), 1352,1189$, 1282; ${ }^{1} \mathrm{H} \mathrm{NMR}\left(400 \mathrm{MHz}, \mathrm{CDCl}_{3}\right)(\delta, \mathrm{ppm})$ : $8.41\left(\mathrm{~s}, 1 \mathrm{H}_{\mathrm{Ar}}\right), 7.89-7.95\left(\mathrm{~m}, 3 \mathrm{H}_{\mathrm{Ar}}\right), 7.80(\mathrm{dd}$, $\left.J=8.7, \quad 1.7 \mathrm{~Hz}, \quad 1 \mathrm{H}_{\mathrm{Ar}}\right), \quad 7.62-7.71\left(\mathrm{~m}, 2 \mathrm{H}_{\mathrm{Ar}}\right)$, $7.39\left(\mathrm{~d}, J=6.0 \mathrm{~Hz}, 1 \mathrm{H}_{\mathrm{Ar}}\right), 7.15(\mathrm{t}, J=7.7 \mathrm{~Hz}$, $\left.1 \mathrm{H}_{\mathrm{Ar}}\right), 6.81\left(\mathrm{dd}, J=8.2,1.8 \mathrm{~Hz}, 1 \mathrm{H}_{\mathrm{Ar}}\right), 6.59$ $\left(\mathrm{s}, 1 \mathrm{H}_{\mathrm{Ar}}\right), 3.75$ (s, $\left.3 \mathrm{H}, \mathrm{OCH}_{3}\right), 3.31\left(\mathrm{~s}, 2 \mathrm{H}, \mathrm{CH}_{2}\right)$.

\section{Protein Expression}

All three isozymes, CA II, CA IX, and CA XII, were produced using the same protocol done for each. Transformation was the first step to be done in which the plasmids and the offspark plasmids of CA II, CA IX, and CA XII were transformed into competent $E$. coli bacteria using the heat shock method, cells were grown in agar, then a colony was selected for further growth in LB broth, cells were collected by centrifugation according to the methods described in [25], and the plasmid was extracted according to the kit protocol using SanPrep col- umn plasmid miniprep kit obtained from Sangon Biotech. The following step was the growing of the HEK-293 cells in DMEM supplemented with $10 \%$ fetal bovine serum (FBS) and $1 \%$ pen/strep mixture, the transfection procedure was conducted seeding the cells in a 96-well plate and addition of the mixture of the plasmid $(0.1 \mu \mathrm{g})$ and Lipofectamine 3000 $(0.2 \mu \mathrm{L})$, incubating the mixture at $37^{\circ} \mathrm{C}$ and $5 \% \mathrm{CO}_{2}$ [26]. Six hours later, the media were aspirated, and the fresh prepared $(+10 \%$ FBS and $1 \%$ pen/strep) media were added to the cells. On the next day, the cells were inspected for their viability, and new media were used for the selection process which were DMEM, FBS, and hygromycin B using a final concentration of $200 \mu \mathrm{g} / \mathrm{mL}$. The cells were grown in the selective media, and when they reached 70 to $80 \%$ confluency, the offspark plasmid transfected cells were checked under a fluorescent microscope to insure the production of the protein; then, the cells transfected with the His-tagged plasmid were collected for making the cell lysate following the method described by [27] by centrifugation of the cells at $2000 \mathrm{rpm}$ for 5 minutes, washed with PBS, and again centrifuged; the pellet was then suspended in the cell lysis buffer, incubated in ice for 15 minutes, and centrifuged again at $10000 \mathrm{~g}$ at $4^{\circ} \mathrm{C}$ for 15 minutes, and here, the pellet was discarded and the supernatant was collected for purification using Ni-NTA Sepharose column according to the manufacturer's protocol [28]. And the eluting solution was quantified using the protein quantification technique Biuret assay and Bradford reagent for protein quantification.

\section{Carbonic Anhydrase Inhibition Assay}

Carbonic anhydrase inhibition activity was carried out using an already developed method [19] with slight modification. The principle of the current method is centered on that "CA hydrolyses the $p$-nitrophenyl acetate to $p$-nitrophenol" which is determined by spectrophotometrically. Reaction mixture contained $60 \mu \mathrm{L}$ of $50 \mathrm{mM}$ Tris-sulfate buffer ( $\mathrm{pH} 7.6$ containing $0.1 \mathrm{mM} \mathrm{ZnCl} 2)$ and $10 \mu \mathrm{L}(0.5 \mathrm{mM})$ test compound in $1 \%$ DMSO. All the ingredients were blended and preincubated for $10 \mathrm{~min}$ at $25^{\circ} \mathrm{C}$. The 96 -well plate reader was used to preread the plates at $348 \mathrm{~nm}$. Preparation of $p$-nitrophenyl acetate was done by taking $6 \mathrm{mM}$ stock using $<5 \%$ acetonitrile in buffer and was used fresh. Each well was filled with $20 \mu \mathrm{L}$ solution to attain $0.6 \mathrm{mM}$ concentration. The total reaction volume was made to $100 \mu \mathrm{L}$. After 30 minutes of incubation at $37^{\circ} \mathrm{C}$, all ingredients were blended and reading was taken at $348 \mathrm{~nm}$. Acetazolamide was used as the standard while DMSO was used as positive controls. The results reported are mean of the three independent experiments $( \pm$ SEM $)$ and expressed as percent inhibitions calculated by the formula,

$$
\begin{aligned}
& \text { Inhibition }(\%) \\
& \quad=[100-(\text { Abs of test comp/Abs of control }) \times 100] .
\end{aligned}
$$

The $\mathrm{IC}_{50}$ values of selected compounds exhibiting $>50 \%$ activity at $1.0 \mathrm{mM}$ were calculated after suitable dilutions [19]. 


\section{Molecular Docking Studies}

Molecular docking study of the most potent inhibitors 24, 23, and 30 was carried out in CA II (PDB ID 3k34), CA IX (PDB ID 5FL4), and CA XII (PDB ID 5MSA), respectively [2-29]. FlexX utility of BioSolveIT's LeadIT program was used for molecular docking [30]. Default parameters of the protein preparation were used to prepare the receptor for docking. The cocrystallized inhibitors inside the carbonic anhydrase isozymes obtained from the protein databank were selected as reference ligand, and the protocol validation was carried out by redocking the cocrystallized inhibitors. After validation of the docking protocol, actual docking of the potent inhibitors was carried out. Hybrid enthalpy and entropy approach of FlexX docking was used for scoring and ranking of the docking poses. The top-ranking poses were then subjected to HYDE assessment and selection of the possible binding mode [31-33].

\section{Data Availability}

The data is already entered in the manuscript. A series of sulfonamide-hydrazide hybrids of aryl and phenyl acetyl hydrazides (19-36) were synthesized and tested for their role as future anticancer agents with less side effects against CA II (major target), CA IX, and CA XII isozymes of the carbonic anhydrase. It was found that substitution of the aromatic group has a significant role in determining the structure activity relationship studies. In the case of aryl substation, when $2 \mathrm{OH}$ group was free, an enhanced activity was observed as compared to the compounds having substituted $\mathrm{OH}$ group with OMe. In the case of acetyl-substituted sulfonamide-hydrazide hybrids, the addition of $\mathrm{CH} 2$ group enhances the activity as compared to the aryl group with one carbon. By using BioSolveIT's SeeSAR software, further studies to provide visual clues to binding affinity indicates that the structural elements that are responsible for this were also studied. Among the entire series, only the compounds 22, 32, and 36 were highly selective inhibitors of hCA IX and did not inhibit hCA XII. We wanted to investigate why binding of these compounds to hCA XII is poor. For this purpose, the compounds 32 and 36 were docked against both hCA IX and hCA XII. Binding of these compounds with hCA IX was highly favorable (as expected) and in agreement with the experimental data.

\section{Conflicts of Interest}

The authors declare that they have no conflicts of interest.

\section{Acknowledgments}

A.M. is thankful to the CUI for providing startup research grant under CIIT. J.I. is thankful to the Higher Education Commission of Pakistan for the financial support through project nos. Ph-V-MG-3/Peridot/R\&D/HEC/2019 and 6927/NRPU/R\&D/17.

\section{Supplementary Materials}

The supplementary material files contain the ${ }^{1}$ HNMR spectra and DFT tables of all the hydrazide-sulfonamide hybrids while ${ }^{13}$ CNMR, EIMS spectra, and HPLC graphs of the selected compounds. (Supplementary Materials)

\section{References}

[1] S. Singh, C. L. Lomelino, M. Y. Mboge, S. C. Frost, and R. McKenna, "Cancer drug development of carbonic anhydrase inhibitors beyond the active site," Molecules, vol. 23, no. 5, p. $1045,2018$.

[2] L. Vats, R. Kumar, S. Bua et al., "Continued exploration and tail approach synthesis of benzenesulfonamides containing triazole and dual triazole moieties as carbonic anhydrase I, II, IV and IX inhibitors," European Journal of Medicinal Chemistry, vol. 183, no. 2019, article 111698, 2019.

[3] P. Taslimi, I. Gulcin, B. Ozgeris et al., "The human carbonic anhydrase isoenzymes I and II (hCA I and II) inhibition effects of trimethoxyindane derivatives," Journal of Enzyme Inhibition and Medicinal Chemistry, vol. 31, no. 1, pp. 152-157, 2016.

[4] G. Koch, "Medicinal chemistry," CHIMIA International Journal for Chemistry, vol. 71, no. 10, p. 643, 2017.

[5] C. T. Supuran, "Carbonic anhydrase inhibitors and their potential in a range of therapeutic areas," Expert Opinion on Therapeutic Patents, vol. 28, no. 10, pp. 709-712, 2018.

[6] C. T. Supuran, "How many carbonic anhydrase inhibition mechanisms exist?," Journal of Enzyme Inhibition and Medicinal Chemistry, vol. 31, no. 3, pp. 345-360, 2016.

[7] B. Z. Kurt, F. Sonmez, D. Ozturk, A. Akdemir, A. Angeli, and C. T. Supuran, "Synthesis of coumarin-sulfonamide derivatives and determination of their cytotoxicity, carbonic anhydrase inhibitory and molecular docking studies," European Journal of Medicinal Chemistry, vol. 183, article $111702,2019$.

[8] T. Gokcen, M. al, I. Topal, T. Gulcin, A. C. Ozturk, and A. C. Goren, "Synthesis of some natural sulphonamide derivatives as carbonic anhydrase inhibitors," Organizational Communication, vol. 10, no. 1, pp. 15-23, 2017.

[9] F. Sonmez, C. Bilen, S. Sumersan et al., "In vitroinhibition effect and structure-activity relationships of some saccharin derivatives on erythrocyte carbonic anhydrase I and II," Journal of Enzyme Inhibition and Medicinal Chemistry, vol. 29, no. 1, pp. 118-123, 2014.

[10] E. B. Cakmak, B. Z. Kurt, D. Ozturk Civelek et al., "Quinolinesulfamoyl carbamates/sulfamide derivatives: synthesis, cytotoxicity, carbonic anhydrase activity, and molecular modelling studies," Bioorganic Chemistry, vol. 110, p. 104778, 2021.

[11] M. D'Ascenzio, S. Carradori, D. Secci et al., "Selective inhibition of human carbonic anhydrases by novel amide derivatives of probenecid: synthesis, biological evaluation and molecular modelling studies," Bioorganic \& Medicinal Chemistry, vol. 22, no. 15, pp. 3982-3988, 2014.

[12] Z. C. Wang, Y. J. Qin, P. F. Wang et al., "Sulfonamides containing coumarin moieties selectively and potently inhibit carbonic anhydrases II and IX: design, synthesis, inhibitory activity and 3D-QSAR analysis," European Journal of Medicinal Chemistry, vol. 66, pp. 1-11, 2013. 
[13] K. D’ Ambrosio, F. Z. Smaine, F. Carta, G. De Simone, J. Y. Winum, and C. T. Supuran, "Development of potent carbonic anhydrase inhibitors incorporating both sulfonamide and sulfamide groups," Journal of Medicinal Chemistry, vol. 55, no. 15, pp. 6776-6783, 2012.

[14] A. Munir, A. Khushal, K. Saeed et al., "Synthesis, _in-vitro_, _in-vivo_anti-inflammatory activities and molecular docking studies of acyl and salicylic acid hydrazide derivatives," Bioorganic Chemistry, vol. 104, p. 104168, 2020.

[15] R. Hosseini, R. Ranjbar-Karimi, and K. Mohammadiannejad, "Synthesis of N-substituted sulfonamides containing perhalopyridine moiety as bio-active candidates," Journal of Fluorine Chemistry, vol. 233, p. 109507, 2020.

[16] S. Zaib, A. Saeed, K. Stolte, U. Flörke, M. Shahid, and J. Iqbal, "New aminobenzenesulfonamide-thiourea conjugates: synthesis and carbonic anhydrase inhibition and docking studies," European Journal of Medicinal Chemistry, vol. 78, pp. 140150, 2014.

[17] J. P. Perdew, K. Burke, and M. Ernzerhof, "Generalized gradient approximation made simple," Physical Review Letters, vol. 78, no. 7, pp. 1396-1396, 1997.

[18] J. P. Perdew, K. Burke, and M. Ernzerhof, "Generalized gradient approximation made simple," Physical Review Letters, vol. 77, no. 18, pp. 3865-3868, 1996.

[19] A. M. Sarotti and S. C. Pellegrinet, "Application of the multistandard methodology for calculating ${ }^{1} \mathrm{H}$ NMR chemical shifts," The Journal of Organic Chemistry, vol. 77, no. 14, pp. 6059-6065, 2012.

[20] A. Saeed, M. al-Rashida, M. Hamayoun, A. Mumtaz, and J. Iqbal, "Carbonic anhydrase inhibition by 1-aroyl-3-(4-aminosulfonylphenyl)thioureas," Journal of Enzyme Inhibition and Medicinal Chemistry, vol. 29, no. 6, pp. 901-905, 2014.

[21] J. Mahar, A. Saeed, K. D. Belfield et al., "1-(2-Hydroxy-5-((trimethylsilyl)ethynyl)phenyl)ethanone based $\alpha, \beta$-unsaturated derivatives an alternate to non-sulfonamide carbonic anhydrase II inhibitors, synthesis via Sonogashira coupling, binding analysis, Lipinsk's rule validation," Bioorganic Chemistry, vol. 84, pp. 170-176, 2019.

[22] "LeadIT version 2.3.2; BioSolveIT GmbH, Sankt Augustin, Germany," 2017, http://www.biosolveit.de/LeadIT.

[23] "SeeSAR version 9.2; BioSolveIT GmbH, Sankt Augustin, Germany," 2019, http://www.biosolveit.de/SeeSAR.

[24] A. Saeed and A. Mumtaz, "Microwave-accelerated synthesis of some 1-aroyl-3,5-dimethylpyrazoles," Chinese Chemical Letters, vol. 19, no. 11, pp. 1305-1308, 2008.

[25] P. Thomas and T. G. Smart, "HEK293 cell line: a vehicle for the expression of recombinant proteins," Journal of Pharmacological and Toxicological Methods, vol. 51, no. 3, pp. 187-200, 2005.

[26] L. Wang, J. Yan, H. Xu, D. Zhang, X. Wang, and J. Sheng, "Expression and purification of the human epidermal growth factor receptor extracellular domain," Protein Expression and Purification, vol. 144, pp. 33-38, 2018.

[27] J. A. Bornhorst and J. Falke, "[16] Purification of proteins using polyhistidine affinity tags," Methods in Enzymology, vol. 326, no. 326, pp. 245-254, 2000.

[28] C. A. Behnke, I. le Trong, J. W. Godden et al., "Atomic resolution studies of carbonic anhydrase II," Acta Crystallographica Section D: Biological Crystallography, vol. 66, no. 5, pp. 616627,2010 .
[29] J. Leitans, A. Kazaks, A. Balode et al., "Efficient expression and crystallization system of cancer-associated carbonic anhydrase isoform IX," Journal of Medicinal Chemistry, vol. 58, no. 22, pp. 9004-9009, 2015.

[30] V. Dudutienè, A. Zubrienè, A. Smirnov et al., "4-Substituted2,3,5,6-tetrafluorobenzenesulfonamides as inhibitors of carbonic anhydrases I, II, VII, XII, and XIII," vol. 21, no. 7, pp. 2093-2106, 2013.

[31] M. Rarey, B. Kramer, T. Lengauer, and G. Klebe, "A fast flexible docking method using an incremental construction algorithm," Journal of Molecular Biology, vol. 261, no. 3, pp. 470489, 1996.

[32] N. Schneider, G. Lange, S. Hindle, R. Klein, and M. Rarey, "A consistent description of HYdrogen bond and DEhydration energies in protein-ligand complexes: methods behind the HYDE scoring function," Journal of Computer-Aided Molecular Design, vol. 27, no. 1, pp. 15-29, 2013.

[33] I. Reulecke, G. Lange, J. Albrecht, R. Klein, and M. Rarey, "Towards an integrated description of hydrogen bonding and dehydration: decreasing false positives in virtual screening with the HYDE scoring function," ChemMedChem: chemistry enabling Drug Discovery, vol. 3, no. 6, pp. 885-897, 2008. 